\title{
Analysis of Aerosol Type and Fine- and \\ Coarse-mode Aerosol Direct Radiative Forcing over Regions in East and Southeast Asia Based on AERONET Version 3 Data
}

Aerosol and Air Quality Research

\author{
Jianyu Lin ${ }^{1}$, Xinyong Shen ${ }^{1,2^{*}}$, Lizhu Xing ${ }^{1}$, Huizheng Che ${ }^{3}$, B.N. Holben ${ }^{4}$ \\ ${ }^{1}$ Key Laboratory of Meteorological Disaster, Ministry of Education/Joint International Research \\ Laboratory of Climate and Environment Change/Collaborative Innovation Center on Forecast \\ and Evaluation of Meteorological Disasters, Nanjing University of Information Science and \\ Technology, Nanjing 210044, China \\ 2 Southern Marine Science and Engineering Guangdong Laboratory (Zhuhai), Zhuhai 519082, \\ China \\ ${ }^{3}$ State Key Laboratory of Severe Weather (LASW) and Key Laboratory of Atmospheric Chemistry \\ (LAC), Chinese Academy of Meteorological Sciences, CMA, Beijing 100081, China \\ ${ }^{4}$ Biospheric Sciences Branch, NASA Goddard Space Flight Center, Greenbelt, Maryland, USA
}

\section{OPEN ACCESS}

Received: August 4, 2020

Revised: March 28, 2021

Accepted: March 30, 2021

${ }^{*}$ Corresponding Author:

shenxy@nuist.edu.cn

\section{Publisher:}

Taiwan Association for Aerosol Research

ISSN: $1680-8584$ print

ISSN: 2071-1409 online

cC) Copyright: The Author(s). This is an open access article distributed under the terms of the Creative Commons Attribution License (CC BY 4.0), which permits unrestricted use, distribution, and reproduction in any medium, provided the original author and source are cited.

\section{ABSTRACT}

Based on the particle linear depolarization ratio (PLDR) and single-scattering albedo (SSA) values obtained for $1020 \mathrm{~nm}$ from Aerosol Robotic Network (AERONET) Version 3 Level 2.0 data collected in five regions, namely, northern China, Northwest Asia, the Tibetan Plateau, southern China and Southeast Asia, we classified seven types of aerosol (viz., purely dust, dust-dominated, pollution-dominated, non-absorbing [NA], weakly absorbing [WA], moderately absorbing [MA] and strongly absorbing [SA]) in order to assess the spatial and temporal distributions of their constituents and the radiative effects of their fine- and coarse-mode particles. The fine fraction dominated in northern China and also played a crucial role on the Tibetan Plateau and in southern China and Southeast Asia, whereas the coarse fraction prevailed in Northwest Asia. Furthermore, the fine-mode aerosol on the Tibetan Plateau exhibited its maximum radiative forcing efficiency $\left(110.3 \mathrm{~W} \mathrm{~m}^{-2}\right)$ during high concentrations of SA aerosol. Also, the lowest values for both the radiative forcing and the radiative forcing efficiency in southern China occurred during summer. Finally, the various aerosol constituents displayed distinct spatial and temporal distributions in Southeast Asia, with the SA aerosol contributing approximately $20 \%$ of the total aerosol on the Indochinese Peninsula and the NA and WA aerosol forming the largest percentages on the Malay Peninsula.

Keywords: Particle linear depolarization ratio, Single scatter albedo, Radiative forcing

\section{INTRODUCTION}

Polyphase aerosol suspended in the air often presents as solid and liquid particles (Sheng et al., 2019). In addition to affecting Earth's radiation balance budget through scattering or absorption of radiation, atmospheric aerosol also impacts the regional and global climate (Zhang et al., 1998a, b; Zhu et al., 2014b; Gui et al., 2017). Aerosol radiative forcing is a crucial indicator of the influence from aerosol on the climate and it is determined by constituents, temporal and spatial variation of concentration, and optical and physical properties of the aerosol (Xia et al., 2007a; Foyo-Moreno et al., 2019). Aerosol causes scattering and absorption of radiation which exerts a cooling or warming effect on the atmosphere, and it has an impact on the atmospheric radiation 
balance (Ramanathan et al., 2008; Zhu et al., 2014; Zheng et al., 2017; Lolli et al., 2019). Different aerosols have diverse optical properties and therefore have different impacts on the climate. As a result, the ability to classify aerosol type has great significant meaning to the forecasting of aerosol radiative effect, which is particularly important in the evaluation of local climates (Satheesh and Krishna Moorthy, 2005).

Although atmospheric aerosol impacts regional and global climate, the high spatial and temporal inhomogeneity makes it difficult to measure the properties and climatic effect of aerosol accurately (Holben et al., 1998). Several ground-based aerosol observation networks have been established to characterize the properties and radiative effect of aerosol, with the Aerosol Robotic Network (AERONET) being one of them (Holben et al., 1998; Xia et al., 2007a). A large global network of robotic stations has been constructed to measure the optical radiative character of aerosol using the CE-318 solar photometer with a $1.2^{\circ}$ full field of view in the absence of precipitation. With eight spectral channels and one moisture band, the CE-318 instrument can retrieve various microphysical and optical parameters of aerosol such as the aerosol optical depth (AOD), single-scattering albedo (SSA) and particle linear depolarization ratio (PLDR) after the inversion of spectral direct and diffuse solar radiation. The uncertainty of AOD derive from AERONET is smaller than 0.01 when the wavelength is larger than $440 \mathrm{~nm}$, smaller than 0.02 when the wavelength is shorter and the uncertainty from calibrated sky radiance is within $5 \%$. The optical parameters data from AERONET official website (https://aeronet.gsfc.nasa.gov/) have been widely used in different aspects, including the aerosol properties, aerosol radiative effect and validate the satellites and models, to improve the understanding about aerosol climatological effect (Liu et al., 2005; Yu et al., 2016).

Researchers have used SSA, the fine-mode fraction (FMF) and other optical parameters from AERONET to classify aerosol species (Schuster et al., 2006). Kim et al. (2007) have used the aerosol index (AI) and FMF from the satellite-based Moderate Resolution Imaging Spectroradiometer (MODIS) to classify aerosol. Shin et al. (2019) have used depolarization and SSA to classify aerosol type, and in contrast with previous studies that used FMF and SSA, classified mineral dust and mixtures of aerosol accurately. Rupakheti et al. (2019) investigate the relationship between four aerosol optical parameters and further differentiate aerosol types, and the conclusion has been validated using CALIPSO observations. Mielonen et al. (2009) distinguished six kinds of aerosol according to their size and spectral absorption based on the Ångström exponent (AE) at 440-870 nm and SSA at $440 \mathrm{~nm}$. Zhu et al. (2014) have used the extinction Ångström exponent (EAE) and absorption Ångström exponent (AAE) to explore the dominant aerosol components in Xinglong, China, with the classification able to retrieve the main types of aerosol transmission trajectories. Based on threshold values for AOD and AE from Toledano et al. (2007), Tan et al. (2015) have distinguished five kinds of aerosol over Southeast Asia during the northwestern monsoon period and southern monsoon period.

Increasingly, researchers are focusing on the PLDR which is sensitive to the shape of particles in lidar measurements (Cairo et al., 1999; Shin et al., 2015; Sheng et al., 2019; Shin et al., 2019). The linear depolarization ratio is defined as the ratio of the cross-polarized lidar return signal to the parallel-polarized backscatter signal (Shimizu et al., 2004; Freudenthaler et al., 2009). Researches have shown that if PLDR values exceed 0.3, the shape of the particles is non-spherical, which implies the dust plume; on the contrary, when the value is closer to 0 , the particle shape is more spherical corresponding to non-dust plume. If the quantity of PLDR is between 0 and 0.3 , the appearance of particle is between non-spherical and spherical particle; as a result, PLDR can easily distinguish fine- mode particles and coarse-mode particles (Freudenthaler et al., 2009; Shin et al., 2015).

Although there are several different methods to identify aerosol category, most methods do not classify the dust component accurately. For example, when using AE and FMF, dust is considered as coarse particle by default. However, some dust is fine-particle dust, and considering dust as coarse-mode particles leads to overestimation of the contribution of mineral dust to AOD and systematic underestimation of the contribution of non-dust particle to AOD (Mamouri and Ansmann, 2017; Shin et al., 2019). Other shortcomings of utilizing AE and FMF as differentiating parameters have been revealed in other studies (Schuster et al., 2006; Lee et al., 2010).

With ongoing economic development in East Asia, aerosol emissions release into the atmosphere have risen and exerting a significant influence on the climate (Gui et al., 2019). To understand 
these trends, further studies about aerosol in Asia are necessary (IPCC, 2013; Balasubramanian et al., 2017). In this work, we use PLDR and SSA at $1020 \mathrm{~nm}$ from AERONET standard measurements to classify atmospheric aerosol over five regions in East Asia and Southeast Asia. We analyze the aerosol optical properties, the spatial and temporal distribution of aerosol components, the radiative forcing effects in each region, and the temporal distribution of radiative forcing and radiative forcing efficiency for fine- and coarse-mode aerosol at five principal stations. The remainder of this paper is organized as follows. In Section 2 we describe the station locations, AERONET data, aerosol optical parameters and classification method. In Section 3, we present the results of our analysis, followed by an analysis of key mechanisms, and finally, we summarize the work and give conclusions in Section 4.

\section{METHODS}

\subsection{Site Description}

We selected 20 sites (stations) from AERONET located at Asia and Southeast Asia, divided into five regions (Fig. 1), to investigate the main types of aerosol at these locations. The five regions are northern China, Northwest Asia, Tibetan Plateau region, southern China and the Southeast Asia. The regions were chosen because they have diverse nature environments and influenced by different anthropogenic activities, making it worthwhile to explore the main aerosol types in each region. We further classified the five regions as either northern area (northern China and

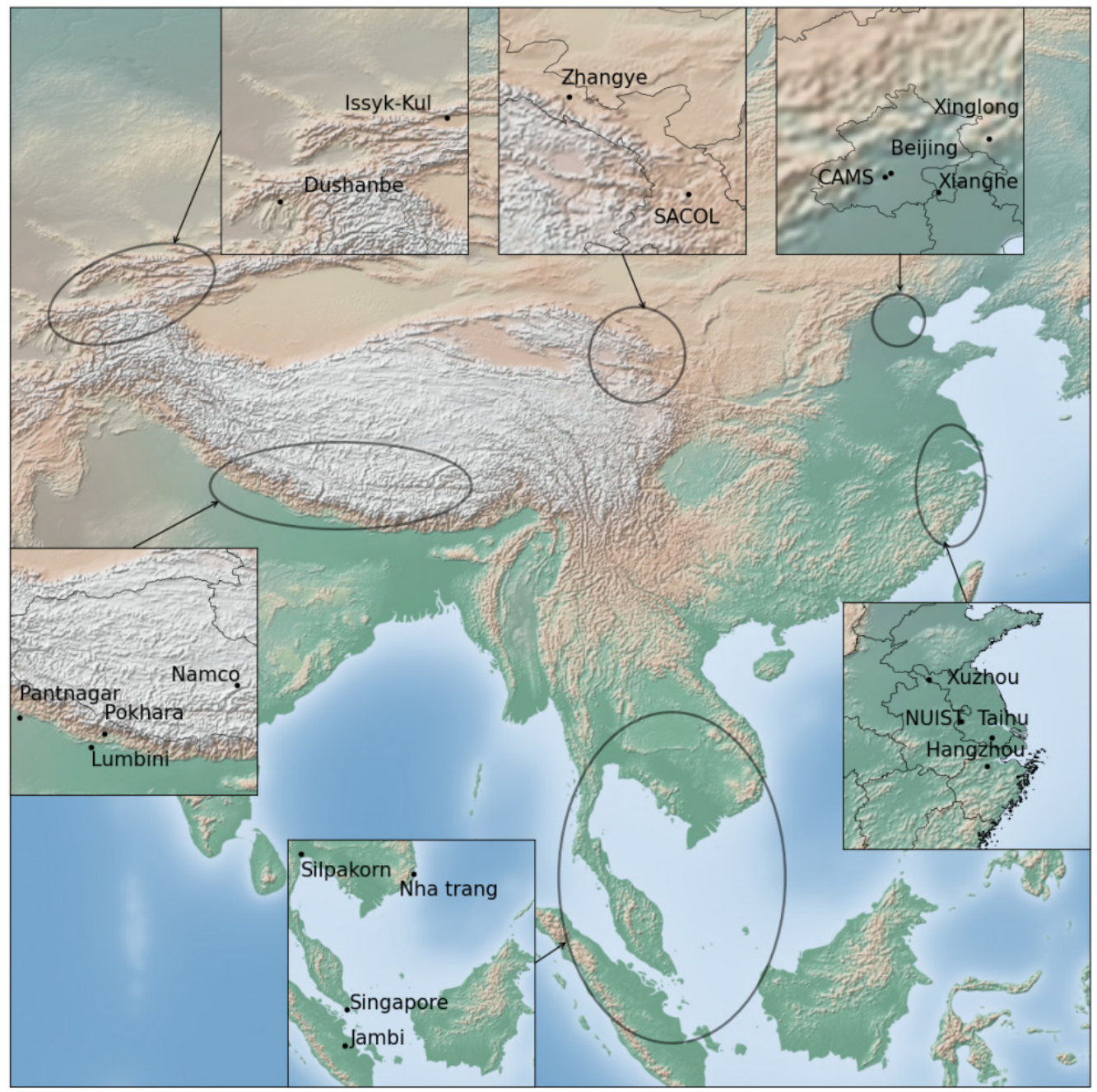

Fig. 1. The locations of the stations in the five regions (shown with black circles) in East Asia and Southeast Asia. 
Table 1. The area classification, latitude, longitude, the observation period and data quality for each station (positive value of latitude means northern latitude, while the negative value means the contrary; Longitude suggests the east longitude).

\begin{tabular}{llllll}
\hline Site & Latitude & Longitude & Period (year) & Valid data amount & Data quality (Level) \\
\hline $\begin{array}{l}\text { Northern area } \\
\text { Beijing }\end{array}$ & 39.98 & 116.38 & $2001-2018$ & 2923 & 2.0 \\
CAMS & 39.93 & 116.32 & $2012-2018$ & 1215 & 2.0 \\
Xianghe & 39.75 & 116.96 & $2001-2017$ & 4303 & 2.0 \\
Xinglong & 40.40 & 117.58 & $2006-2014$ & 442 & 2.0 \\
Dushanbe & 38.55 & 68.86 & $2010-2018$ & 925 & 2.0 \\
Issyk-Kul & 42.62 & 76.98 & $2007-2019$ & 9810 & 1.5 \\
SACOL & 35.95 & 104.14 & $2006-2013$ & 1128 & 2.0 \\
Zhangye & 39.08 & 100.28 & $2008-2008$ & 191 & 1.5 \\
Southern area & & & & & 2.0 \\
Lumbini & 27.49 & 83.28 & $2013-2018$ & 1164 & 1.5 \\
Namco & 30.77 & 90.96 & $2006-2017$ & 2749 & 2.0 \\
Pantnagar & 29.046 & 79.52 & $2008-2009$ & 474 & 2.0 \\
Pokhara & 28.19 & 83.98 & $2010-2018$ & 1949 & 2.0 \\
Hangzhou & 30.29 & 120.16 & $2008-2009$ & 213 & 1.5 \\
NUIST & 32.21 & 118.72 & $2007-2010$ & 426 & 1.5 \\
Taihu & 31.42 & 120.22 & $2005-2018$ & 4626 & 1.5 \\
Xuzhou & 34.22 & 117.14 & $2013-2019$ & 4631 & 2.0 \\
Jambi & -1.63 & 103.64 & $2012-2016$ & 78 & 1.5 \\
Nha Trang & 12.20 & 109.21 & $2011-2019$ & 2156 & 2.0 \\
Silpakorn & 13.82 & 100.04 & $2006-2019$ & 7059 & 303 \\
Singapore & 1.30 & 103.78 & $2006-2018$ & 3 &
\end{tabular}

Northwest Asia) or southern area (the plateau region, southern China and Southeast Asia) depending on their geographic locations. To account for heterogeneity in aerosol optical parameters and radiative effect, four stations were selected in each region. The detail information with respect to station including observation period and data quality are shown in Table 1 . The Level 1.5 and Level 2.0 data are all cloud-screened data but the Level 2.0 data have pre- and post-field calibrated (Smirnov et al., 2000; Che et al., 2014). We utilize the Level 2.0 data to investigate the aerosol climatological effect in principle, but for the stations without PLDR data in the Level 2.0 dataset, it will be replaced by the corresponding Level 1.5 data. In the following sections, we describe the spatial and temporal variations of seven kinds of components, and the aerosol radiative properties for all stations.

\subsection{Aerosol Optical Parameters}

A comprehensive understanding of optical parameters and the ability to classify aerosol types helps greatly in the understanding ambient air quality (Holben et al., 2001). Dubovik et al. (2006) has suggested PLDR could be retrieved from AERONET, in which sun-sky radiometers are used to observe aerosol microphysical properties (Dubovik et al., 2006). PLDR from AERONET is calculated as in Eq. (1):

$\delta(\lambda)=\frac{1-F_{22}\left(\lambda, 180^{\circ}\right) / F_{11}\left(\lambda, 180^{\circ}\right)}{1+F_{22}\left(\lambda, 180^{\circ}\right) / F_{11}\left(\lambda, 180^{\circ}\right)}$

where $\lambda$ and $180^{\circ}$ is the wavelength in each channel and the scanning angle, respectively. The $F_{11}$ and $F_{22}$ of the Müller scattering matrix are calculated using the particle size distribution and complex refractive index (Bohren and Huffman, 2008). When the incident light is unpolarized, $F_{11}$ has a positive relationship with the flux of scattered light, while $F_{22}$ is strongly affected by the angular and spectral distribution of the radiative intensity.

As the normalized value of particle linear depolarization ratio, the dust ratio $\left(R_{d}\right)$ is an optical parameter that can be used to identify dust and non-dust particles in a mixture of aerosol (Tesche 
et al., 2011). The importance of $R_{d}$ is that it can quantify the contribution of dust compared with the total backscattering coefficient of the aerosol mixture. Assuming that coarse-mode aerosol and fine-mode aerosol are externally mixed, $R_{d}$ can be calculated as:

$R_{d}=\frac{\left(\delta-\delta_{2}\right)\left(1+\delta_{1}\right)}{\left(\delta_{1}-\delta_{2}\right)(1+\delta)}$

where $\delta$ is the PLDR as measured by solar photometer at $1020 \mathrm{~nm} . \delta_{1}$ and $\delta_{2}$ represent the PLDR of coarse-mode and fine-mode aerosol, respectively, with both of them determined based on previous studies (Shin et al., 2018). Values of 0.3 for $\delta_{1}$ and 0.02 for $\delta_{2}$ were used to calculate $R_{d}$. When $R_{d}$ is larger than 1 or smaller than $0, R_{d}$ is set to 1 or 0 , respectively, so the range of $R_{d}$ is from 0 to 1 .

The absorption aerosol optical depth (AAOD) and AAE optical parameters are calculated using Eqs. (3) and (4), respectively:

$\operatorname{AAOD}(\lambda)=[1-\operatorname{SSA}(\lambda)] \times \operatorname{AOD}(\lambda)$

$A A E=-d \ln [A A O D(\lambda)] / d \ln (\lambda)$

$A A O D$ is a quantitative indicator: $A$ higher $A A O D$ means there are more absorptive aerosol in the air mass. AAE can be regarded as an indicator of the dominant absorptive aerosol types. AAE is a qualitative parameter, so a larger value of $A A E$ corresponds to stronger absorption for the aerosol. A comprehensive evaluation of AAOD and AAE is essential in the analysis of optical properties of aerosol.

Under the cloud-free assumption, a radiative transfer module can calculate the direct radiative forcing (ADRF) in AERONET (García et al., 2008). ADRF is defined as the difference in the net solar radiative flux in the presence of aerosol $\left(\mathrm{F}^{\mathrm{P}}\right)$ and in the absence of aerosol $\left(\mathrm{F}^{\mathrm{A}}\right)$, as in Eq. (5):

$A D R F=\left(F^{\downarrow P}-F^{\uparrow P}\right)-\left(F^{\downarrow A}-F^{\uparrow A}\right)$

The up and down arrows indicate the upward and downward flux of solar radiation, respectively. The ADRF at the top and bottom of the atmosphere from the AERONET is defined as FTOA and $F_{B O A}$, and shown in Eqs. (6) and (7), respectively. The gap between $F_{\text {TOA }}$ and F $_{\text {BOA }}$ is the solar radiative energy stored in the $\operatorname{air}(\Delta \mathrm{F})$ and as shown in Eq. (8). Positive values of $\Delta \mathrm{F}$ indicate solar energy store in the atmosphere while negative values of $\Delta \mathrm{F}$ indicate the contrary.

$\mathrm{F}_{\mathrm{TOA}}=\left(\mathrm{F}_{\mathrm{TOA}}{ }^{\mathrm{A}}-\mathrm{F}_{\mathrm{TOA}}{ }^{\uparrow P}\right)$

$F_{B O A}=\left(F_{B O A}{ }^{\downarrow P}-F_{B O A} \downarrow A\right)$

$\Delta \mathrm{F}=\mathrm{F}_{\mathrm{TOA}}-\mathrm{F}_{\mathrm{BOA}}$

Another parameter, the radiative forcing efficiency, defined as the rate at which the atmosphere is forced per unit of AOD (Che et al., 2014), has been widely used in previous studies. The radiative forcing efficiency in the air is calculated as:

$F_{\text {eff }}=\frac{\Delta F}{A O D_{500 n m}}$

\subsection{Classification Method}

Using the threshold of $R_{d}$ which was calculated from PLDR and SSA at $1020 \mathrm{~nm}$, seven kinds of aerosol were classified on the basis of aerosol size and their spectral absorption. The reliability of PLDR derive from AERONET products has been proved by previous research, which has shown high correlation between PLDR (especially at $1020 \mathrm{~nm}$ ) from AERONET and data from Mie scattering lidars in East Asia (Noh et al., 2017). Shin et al. (2019) obtained PLDR from AERONET 
Level 2.0 Version 3 products to retrieve the main aerosol types and their optical properties in East Asia (Shin et al., 2019). The boundary between dust and non-dust aerosol could be clearly identified by PLDR at $1020 \mathrm{~nm}$. Following this distinguish method, the threshold values were generated.

As shown in Fig. 2, the flow chart presents the classification method specifically. $R_{d}$ was used to distinguish fine-mode aerosol and coarse-mode aerosol firstly, which reveal that the content of dust is the criteria between fine- and coarse-mode aerosol in this article. $R_{d}$ values below 0.17 indicate fine-mode aerosol; the rest of particle will be recognized as coarse-mode aerosol. In the range of coarse-mode aerosol, $\mathrm{Rd}$ values exceeding 0.89 are regarded as pure dust. The value of 0.53 (the middle value between 0.89 and 0.17 ) can separate two kinds of dust-pollution mixed aerosol according to the magnitude of the different components; the mixture is either dust-dominated aerosol (more dust components) or pollution-dominated aerosol (less dust components).

Secondly, to further identify aerosol types based on spectral absorption, fine-mode aerosol was distinguished by using SSA. The absorptive effect produced by the interaction between aerosol and solar radiation occurs over the wavelength band spanning near-infrared to shorter visible wavelengths (Lee et al., 2010). Strong absorption aerosol mainly with a weak wavelength dependence (such as black carbon), which implies that it reveals strong ability of absorption both at blue wavelengths and near-infrared wavelengths, different from other aerosols showing absorption mostly in blue wavelength. Furthermore, previous research has also proposed that the SSA of different aerosol types has a wide range at near-infrared wavelength than at shorter wavelengths (Hess et al., 1998).

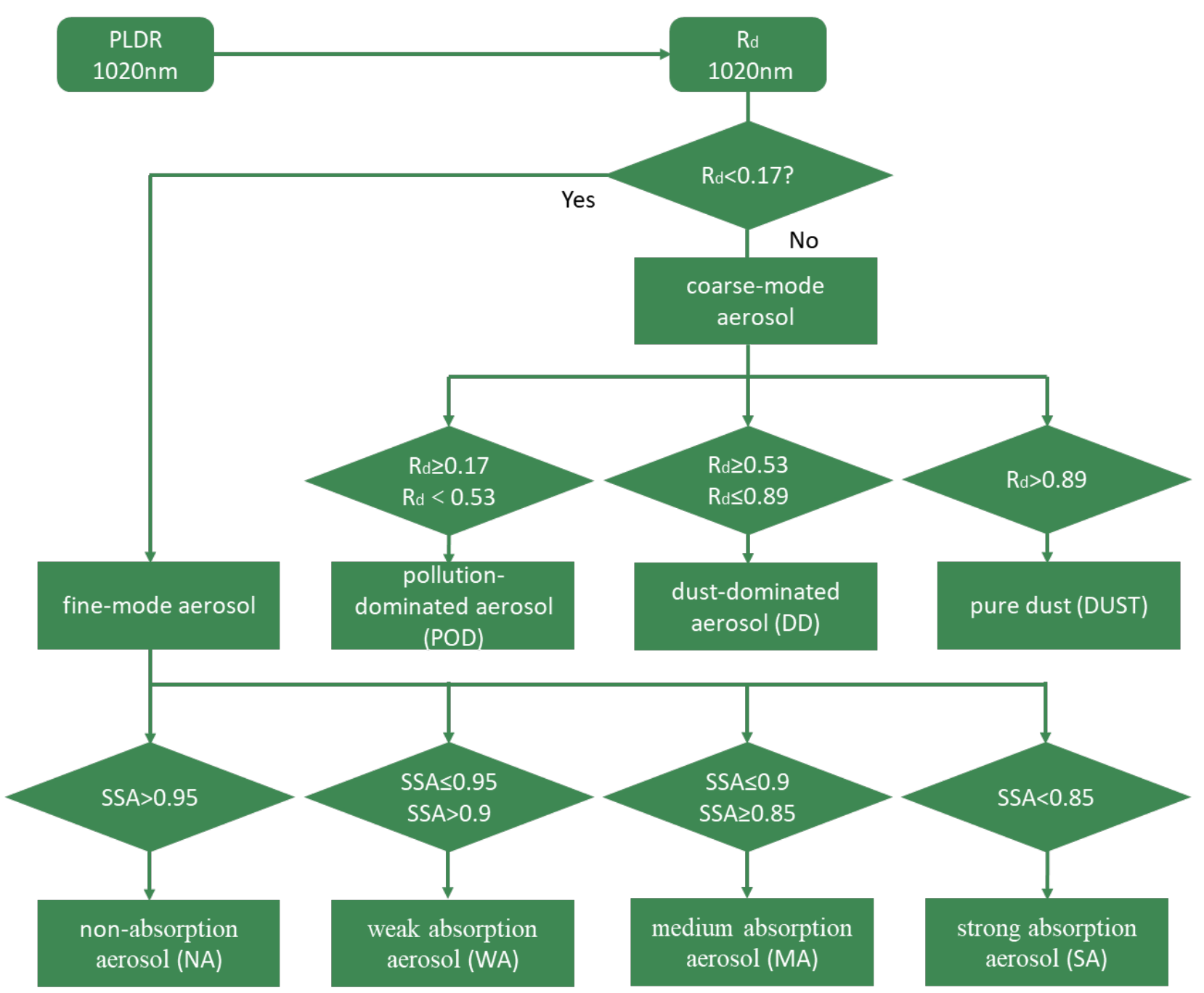

Fig. 2. Flow chart in terms of aerosol identification based on PLDR, SSA in $1020 \mathrm{~nm}$. 
For the reasons above, SSA at $1020 \mathrm{~nm}$ was used to identify the absorption of aerosol. An SSA value of 0.95 can be used as a threshold to judge whether particles are absorptive or not (Shin et al., 2019). As a result, SSA $>0.95$ indicates non-absorbing (NA) aerosol. Absorptive aerosol constituents have been further distinguished by their spectral absorption, such as weakly absorbing (WA; $0.9<\mathrm{SSA} \leq 0.95$ ) aerosol, moderately absorbing (MA; $0.85 \leq \mathrm{SSA} \leq 0.9$ ) aerosol, and strongly absorbing (SA; SSA $<0.85)$ aerosol.

\section{RESULTS AND DISCUSSION}

\subsection{Optical Parameters in the Northern and Southern Areas}

We analyzed the distribution of $A O D, A E$, fine-mode $A O D$, coarse-mode $A O D, A A O D, A A E$ in Figs. 3 and 4, to investigate the optical radiative properties of aerosol in each region; the AOD, fine and coarse-mode $A O D, A A O D$ are all from $440 \mathrm{~nm}$, while the $A E$ and $A A E$ are in the wavelength of $440-870 \mathrm{~nm}$. AOD measures the ability of backward extinction from aerosol to incident radiation. AOD exceeding 0.4 has great significance to the inversion of other parameters. To ensure the reliability of optical parameter estimation, we restricted the analysis to periods when $A O D>0.4$. The AOD of fine-mode and coarse-mode aerosol represents the extinction effect of fine and coarse particles, respectively. $A E$ is a vital indicator of the size of particles; high $A E$ values are associated with smaller aerosol radii, whereas particles with low AE are generally coarsemode. If $A E(440-870 \mathrm{~nm})<0.75$, coarse-mode particles dominate in the environment, and if $A E$
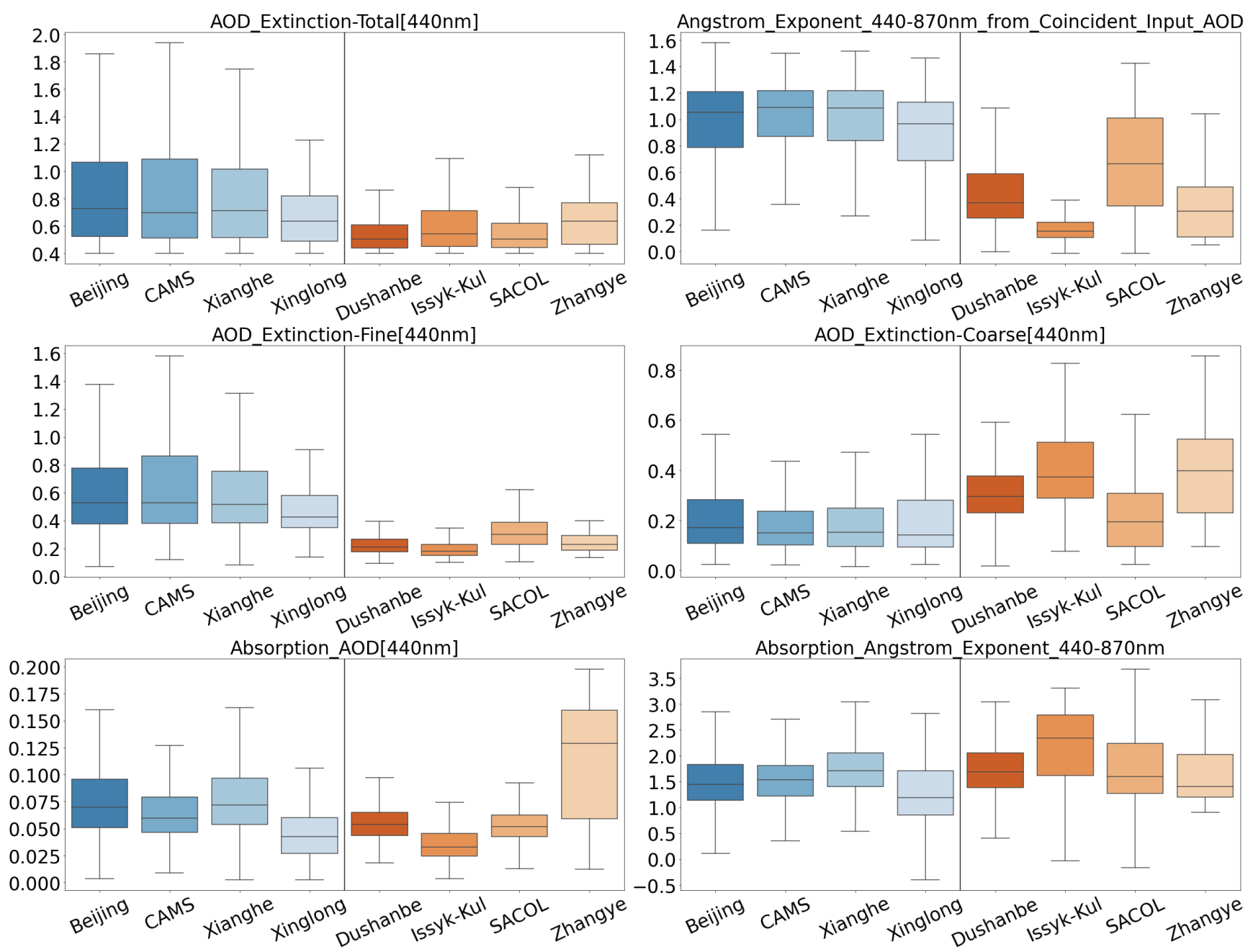

Fig. 3. Box plots of $A O D, A E$, fine-mode $A O D$, coarse-mode $A O D, A A O D, A A E$ for eight stations in the northern area. The blue boxes and red boxes represent the stations in northern China and northwestern Asia. 
$(470-870 \mathrm{~nm})>1.0$, fine-mode particles is more prevalent in the air; $A E(470-870 \mathrm{~nm})$ values between 0.75 and 1.0 suggest complicated aerosol components (Wang et al., 2014). AAOD measures the quantity of absorptive aerosol in the air; a large value of AAOD is corresponding to high concentration of absorptive aerosol in the air. As a vital indicator of ability of aerosol absorption, $A A E<1$ indicates that the aerosol is mixed with coating and coagulation of black carbon with organic and inorganic material. AAE close to 1 indicates black carbon aerosol from fossil fuel burning. Finally, $A A E>1.10$ indicates absorptive aerosols mainly from biomass burning or mineral dust (Bergstrom et al., 2007; Russell et al., 2010).

The mean values of AOD in northern area stations is $0.87,0.86,0.83,0.72,0.58,0.62,0.58$, 0.63 (Fig. 3). AOD in northern China is higher than that in Northwest Asia, which indicates that air quality is worse in northern China. The extinction effect of aerosol in northern China is stronger than that in Northwest Asia. AE is $0.96,1.02,1.00,0.89,0.45,0.22,0.67,0.40$ at the stations. The mean radius of aerosol in Northwest Asia is larger than that in northern China, because Northwest Asia is dominated by a desert environment (Ma et al., 2017). Combined with the fine-mode and coarse-mode extinction results, the mean values of coarse-mode AOD is 0.28 in Northwest Asia suggest that coarse-mode aerosol is the main component of aerosol in Northwest Asia. The mean values of fine-mode AOD extinction in northern China is 0.43 ; under the influence of intensive emissions from anthropogenic activity, fine-mode particles are more prevail in northern China (Che et al., 2014).

With the exception of the Zhangye station, AAOD in northern China (can reach 0.06) is higher than that in Northwest Asia. The release of fine-mode particles from residential heating especially during the winter is the main contributor to produce more absorptive aerosol in northern China (Zhao et al., 2015). However, AAOD at the Zhangye station is 0.11 , suggesting that Zhangye suffers from higher concentrations of mineral dust. AAE in Northwest Asia is 1.84, higher than that in northern China (1.52). The higher AAE in Northwest Asia indicates the presence of strong absorptive aerosol; for instance, the iron oxide present in the mineral dust will considerably enhance aerosol absorption. The magnitudes of AAOD and AAE suggest that there is more absorptive aerosol in northern China, but with relative weak absorption, and less absorptive aerosol in Northwest Asia but with relatively stronger absorption.

In Fig. 4, we show results for 12 stations in the three southern regions. It is worthy to noticing that the incident which AOD > 0.4 is rare in Namco; as a result, the article will not take the data from this station into account when calculate the mean values. The mean values of observed AOD in the plateau area, southern China, and southeastern Asia is $0.85,1.04$, and 0.91 , respectively. The highest values of total AOD are at Jambi, which may be the result of large number of hotspots in dry season (Kusumaningtyas et al., 2019). Mean values of $A E$ at the plateau area, southern China, and southeastern Asia is 1.40, 1.31, 1.51, respectively, suggest that the sites above are all dominated by fine-mode aerosol. In terms of fine-mode AOD and coarse-mode AOD, the distribution of fine-mode $A O D$ values at all stations is similar with $A O D$, which means that fine-mode aerosol in the three southern areas contributes greatly to the local AOD, much larger than the respective coarse-mode contributions. The coarse-mode aerosol contribution to AOD in southern China is larger than that in the other two regions, with mean values reaching 0.06 and this phenomenon may be the result of long-distance transport of dust in spring (Chen et al., 2009). In the plateau region, Namco has clean ambient air; the Namco station located at a higher altitude and there is less anthropogenic activity, leading to a pristine environment (Che et al., 2015), as a result, is susceptible to anthropogenic aerosol from the south of the Himalayan mountains, as well as emission from other regions. In the south of the Tibetan Plateau, the frequency of anthropogenic activity is higher, with more biomass burning and contribute greatly to the dominance of fine-mode aerosol (Ramanathan and Ramana, 2005; Rupakheti et al., 2017; Wan et al., 2017). Accumulationmode particles are more susceptible to hygroscopic growth than coarse particles, which is conducive to the increase in AOD in southern China. Furthermore, the abundant moisture in southern China results in hygroscopic growth of fine particles in June and September, strengthening scattering and extinction (Che et al., 2018; Sun et al., 2019). The reasons above lending to high value of fine-mode AOD in southern China. Owing to biomass burning, emissions of anthropogenic aerosol, and to its remoteness from dust sources, fine-mode aerosol is dominant in Southeast Asia. Natural aerosol is also produced in this region, including from forest fires and volcanic eruptions; emission produced from incomplete combustion biofuels and forest fires also facilitates the 

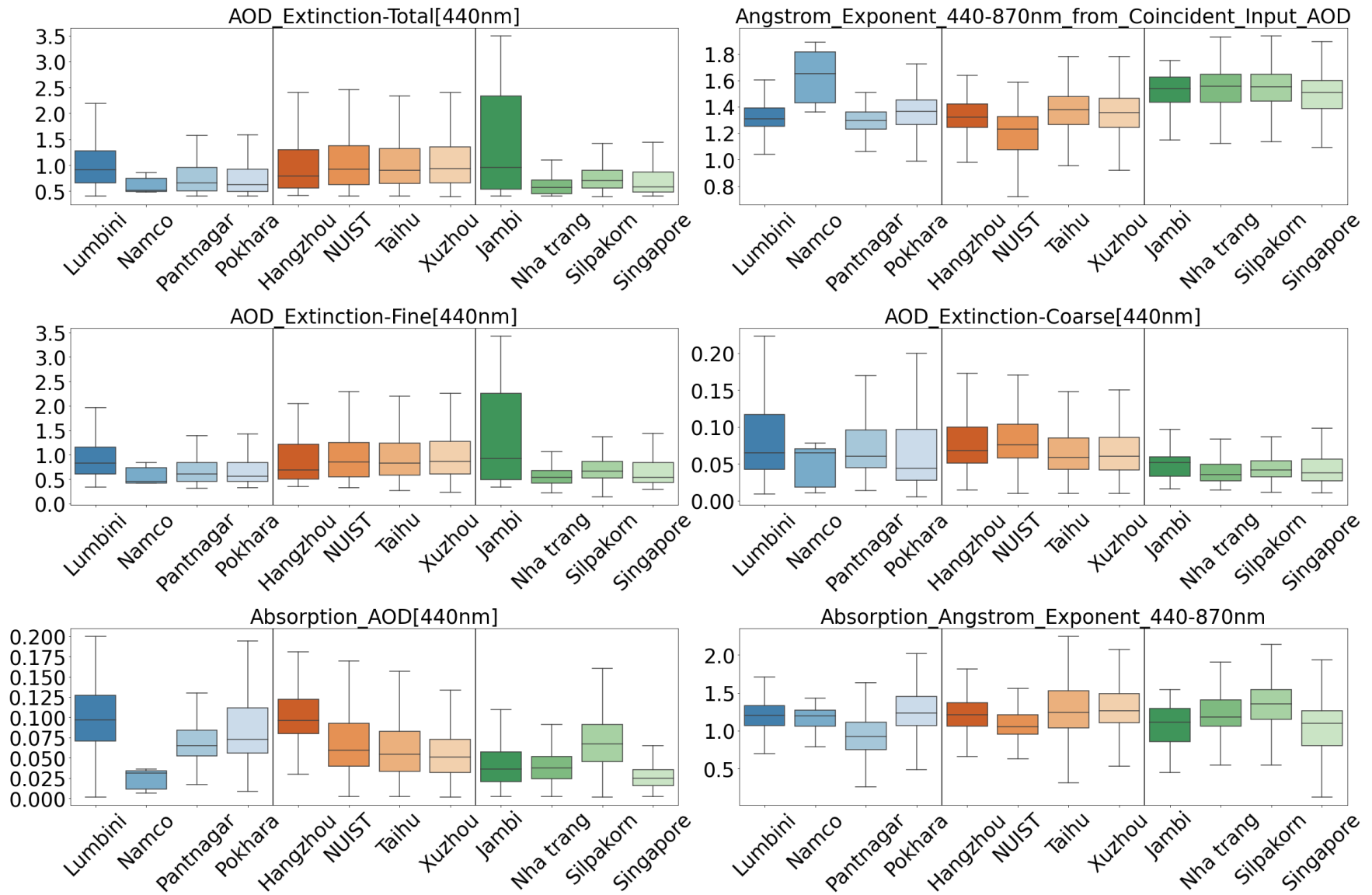

Fig. 4. As in Fig. 3 but for 12 stations in the southern area. The blue, red and green boxes suggest stations in Tibetan Plateau, southern China, and Southeast Asia, respectively.

increase in AOD in Southeast Asia. Emissions from vehicles in densely populated urban areas, such as Singapore, also increase fine-mode emissions (Salinas et al., 2009).

AAOD in the plateau region, southern China, and Southeast Asia is $0.08,0.06,0.04$, respectively. In the plateau region, large numbers of SA aerosol, such as black carbon produced by agricultural activities and biomass burning, have strong absorption, which may release into the atmosphere manifests as high AAOD values in the plateau. Abundant moisture in southern China enables hygroscopic growth of aerosol, which increases scattering and gives rise to lower AAOD (Che et al., 2018). High-relative-humidity environments are also present in Southeast Asia. The low level of AOD in Southeast Asia may be the contributor to the lower values of AAOD there when compared with southern China. Finally, the AAE in each region is $1.13,1.20,1.15$, respectively. Combine with previous studies, high AAE is mainly induced by local biomass burning in southern regions.

\subsection{Spatial and Temporal Distribution of Seven Different Aerosol Components}

\subsubsection{Spatial distributions at each station}

The spatial distribution of seven kinds of aerosol components are shown in Fig. 5, which shows that pollution-dominated aerosol (POD) dominates the composition of air masses at the stations in northern China, which makes up about $\sim 30 \%$ of total aerosol. With economic development and growth, there is more fine-mode aerosol in the air. NA and WA aerosol, with relatively weak absorptivity but strong scattering of solar radiation, make up a large proportion compared with others aerosol types. Pure dust makes up $\sim 2 \%$ of total aerosol in northern China, which is similar to previous results (Shin et al., 2019).

Aerosol type in southern China is mainly dominated by fine-mode aerosol. The most evident difference between the northern and southern regions is dust accounts for a much lower percentage of total aerosol in southern China. In addition, the high-humidity conditions in southern China 


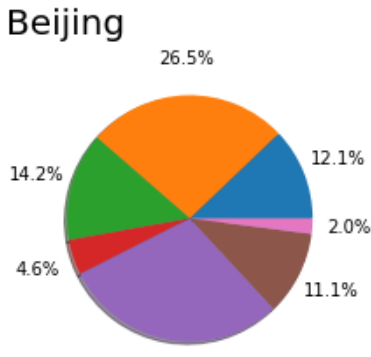

$29.5 \%$
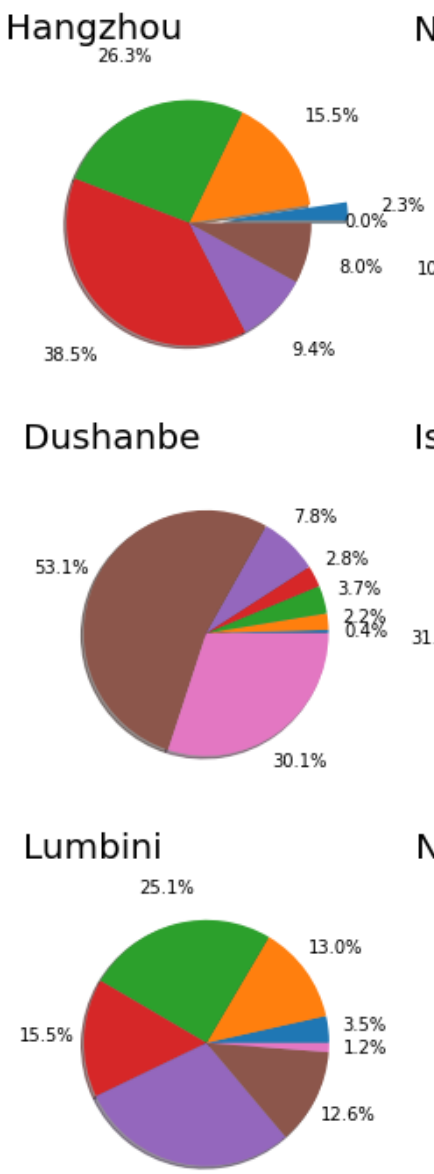

$29.0 \%$

Jambi

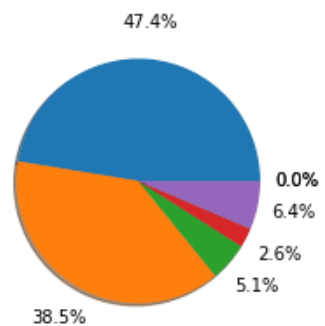

CAMS

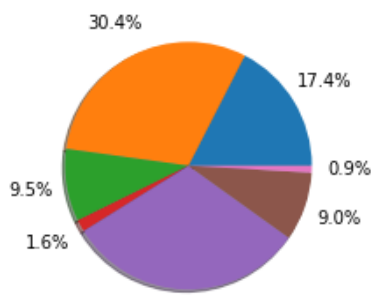

$31.3 \%$

NUIST

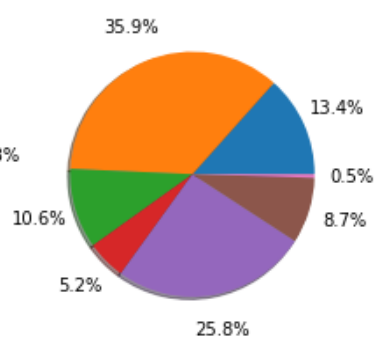

Issyk-Kul

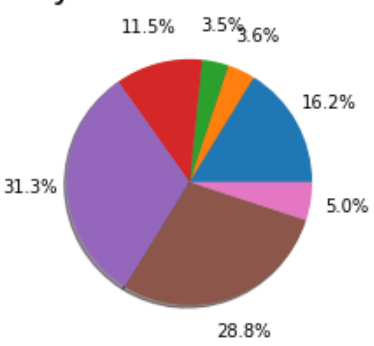

Nam_co

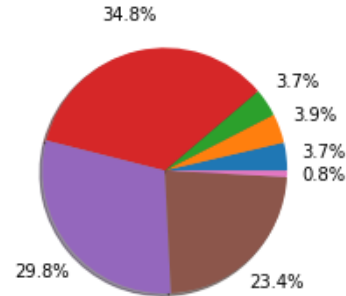

Nha trang

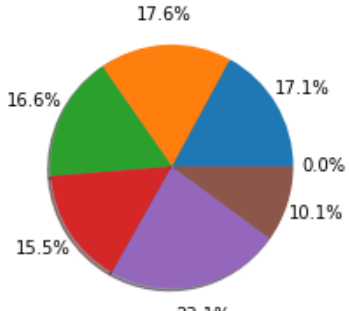

Xianghe

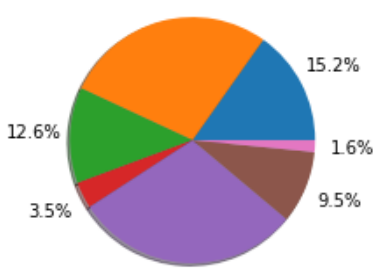

$29.8 \%$

Taihu

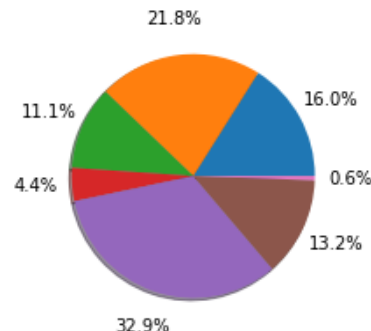

SACOL

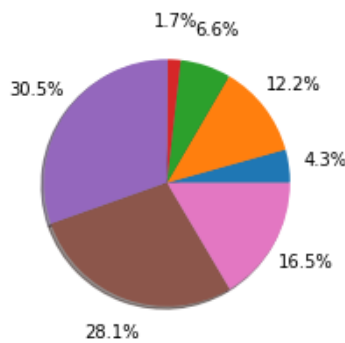

Pantnagar

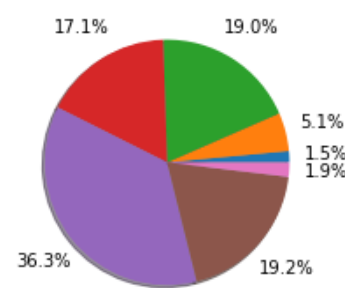

Silpakorn

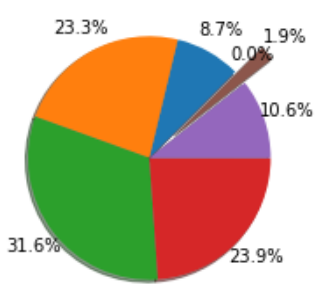

Xinglong
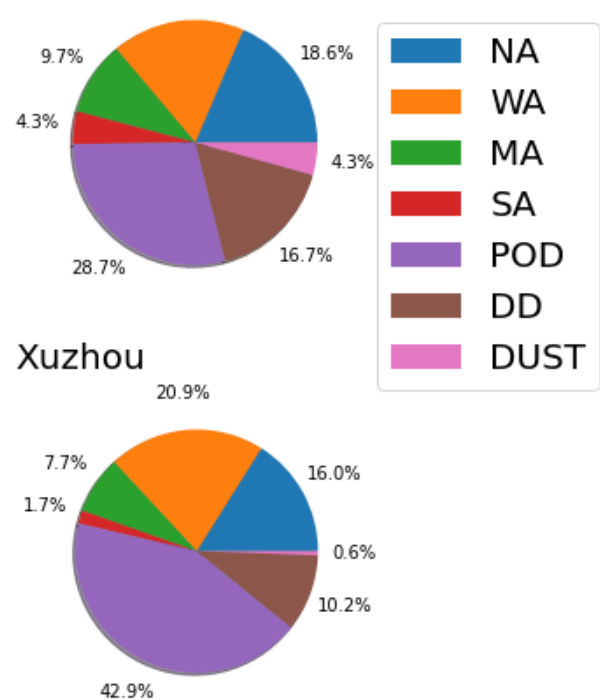

Zhangye ${ }_{22.5 \%}$

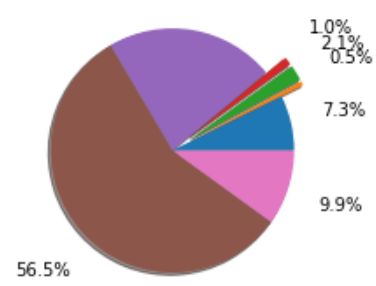

Pokhara

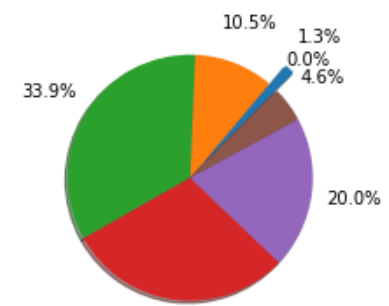

$29.7 \%$

Singapore

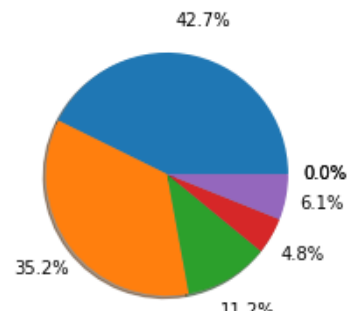

Fig. 5. Pie charts showing the percentage composition of several different aerosol types based on long-term observations at the 20 stations. They are from northern China, southern China, Northwest Asia, the Tibetan Plateau, and Southeast Asia. The DD is dust-dominated aerosol and the DUST means the pure dust.

will facilitate photochemical processes; the sulfate produced from these interactions is one of the reasons why there is more fine-mode aerosol in southern China (Li et al., 2015). A higher concentration of SA have observed in Hangzhou than other southern China station, which have 
a good agreement with previous researchers who suggested that there are more absorptive aerosol, such as released by biomass burning and industrial activities, gathers in urban sites (Che et al., 2018).

The proportions of DD and POD are greatly increased in Northwest Asia and play a leading role in determining local aerosol type. There are many sources of sand and dust, with desertification a serious problem. For example, at the Dushanbe station, pure dust accounts for over $30 \%$ of the aerosol. The northwestern region of Asia is a significant channel for dust transport to China. Under the influence of the Mongolian cyclone in spring and winter, dust will gradually affect the west, north and the south of China (Zhang et al., 2012).

Biomass burning in the south of the plateau should account for the large proportion of SA aerosol in the plateau region. The aerosol comes from anthropogenic activity, with biomass burning in the south of the Himalayan mountains producing large amounts of aerosol with strong absorption (such as black carbon). Lifted by the southwestern wind, the fine-mode particles pass through the Himalayas and then affect air mass composition in the plateau (Zhu et al., 2019), such as the Namco station. The DD and POD in the plateau region may also be the result of longdistance transport of sand and gravel from the Taklamakan Desert.

The main types of aerosol in the Southeast Asia region are fine-mode aerosol, similar to the results from southern China. However, it is clear that there is more SA aerosol and less POD in Southeast Asia than in southern China, which implies the decreasing of PLDR and the particles reveal more spherical in Southeast Asia than those in southern China. An interesting finding in terms of the spatial distribution of aerosol type in Southeast Asia is that the aerosol type in the Indochinese Peninsula is different from that in the Malay Archipelago. SA aerosol accounts for $\sim 20 \%$ of total aerosol in the Indochinese Peninsula, with biomass burning and forest fires generating aerosol such as black carbon. At lower latitudes in Southeast Asia, there is a lower proportion of SA aerosol and a higher proportion of NA aerosol in Malay Peninsula. There is a large proportion of NA aerosol than any other aerosol type in the Malay Peninsula, which may be the result of the vehicle emissions from metropolitan areas.

\subsubsection{Temporal distributions of seven aerosol components at five principal stations}

We chose one station from each of the five regions to investigate the temporal variations of seven aerosol types over the whole observed period in Fig. 6. Each of the stations is affected by aerosol emissions from natural sources and anthropogenic activity.

In northern China (Beijing), fine-mode particles make up a large proportion of total aerosol in the air mass, except in March, April and May. Dust is transported to downwind areas by dust storms, especially in spring (Huebert et al., 2003; Eck et al., 2005; Eck et al., 2010; Cao et al., 2014). The Mongolian cyclone develops during most winters; under its influence, and with abundant desert in central Asia, the proportion of POD and coarse particles increases in spring. The maximum values of dust proportion occur in April due to dust being carried with strong northwesterly winds, while with much lower values in other months. In the following months, the fine-mode particle concentration increases rapidly, reaching a maximum in July corresponding to the change in wind direction. The large proportion of SA aerosol in winter suggests an increase in emissions from residential heating.

Similar with the situation in northern China, coarse-mode particle concentrations increase during spring in southern China (Taihu), as a result of long-distance transport of dust plumes, but pure dust is scarce in this region over the whole year. Fine-mode aerosol makes up a large proportion of total aerosol in June and August in southern China. When the subtropical anticyclone moves northwards, southeasterly winds facilitate moisture transmission to Taihu in June, which is favorable to the hygroscopic growth of fine-mode aerosol. Furthermore, the humid surroundings also provide a humid environment in Taihu (Khan et al., 2019). It is interesting that fine-mode aerosol concentrations reach a maximum in June and August in Taihu, representing the movement of the subtropical anticyclone northwards and then back to the south, respectively. The strong relationship between the anticyclone position and the fine-mode particle concentration is also evident from the Beijing observations. When the anticyclone moves northward in July and August, fine-mode aerosol concentrations in Beijing reach their climax. As the anticyclone later 

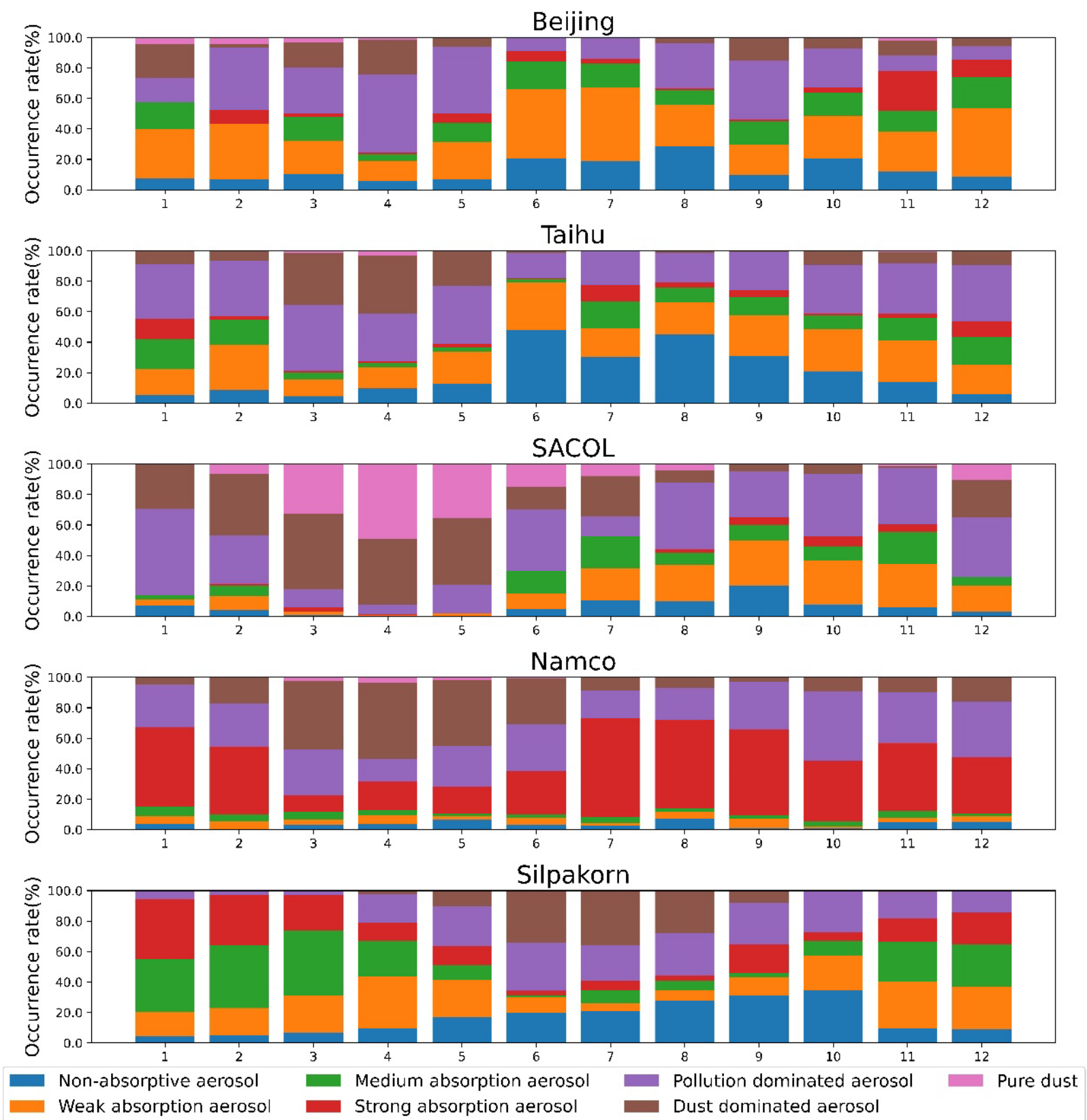

Fig. 6. Monthly occurrence rates for seven aerosol components at five representative stations, presenting the seasonal variational of the components over the whole year.

move southward, the fine-mode aerosol concentrations decrease until the SA aerosol concentration increases in December. The relatively high concentration of SA aerosol in July and during winter may result from biomass burning and combustion of coal, respectively.

In Northwest Asia (SACOL), dust and coarse-mode aerosol are dominant over the whole year. The occurrence of fine-mode aerosol increases in summer, and reaches a maximum in September, but fine-mode aerosol is rarely observed in spring. This phenomenon can be explain by fewer dust storms in autumn and winter compared with spring and summer (Gong et al., 2003). Northwest Asia experiences high wind speeds and low levels of atmospheric moisture, which favors dust emission, and dust plumes play a crucial role in winter and spring (Xin et al., 2016). The coarse-mode aerosol dominance in spring corresponds to the maximum in wind speed, which occurs in March and April (Deng et al., 2014).

Compared with the other regions, the occurrence rate of SA aerosol is higher in the plateau region (Namco) for the whole year. DD and POD aerosol are prevalent in the plateau region from 
March to July due to sources in the Taklamakan Desert and strong wind speeds, especially in spring. With increasing anthropogenic activity in summer, the occurrence rate of SA aerosol increases rapidly. Biomass burning in India and Nepal associated with agriculture activity in summer also contributes greatly to the high concentrations of SA aerosol in summer. After a brief dip in October, the occurrence rate of SA aerosol rises again in winter as a result of combustion of coal and other fossil fuels, as well as agricultural activity in the southern Tibetan Plateau, in agreement with the findings of previous research (Rupakheti et al., 2019).

In Southeast Asia (Silpakorn), aerosol types are under the influence of the Asian monsoon circulation. There is an increasing proportion of SA aerosol in Silpakorn in winter, while coarsemode aerosol takes up a large proportion in summer than the other seasons. In winter, the strong northeastern monsoon is underway, which take larger magnitude of SA aerosol (mostly comes from biomass burning and anthropogenic activities) from the Indochinese Peninsula to the coastal area (Feng and Christopher, 2013). With the wind direction change to southwest, coarsemode aerosol comes from ocean are dominated in June, the monsoon blows from ocean to the land also contribute to an increasing proportion of NA in summer.

\subsection{Radiative Forcing in the Northern and Southern Area}

Radiative forcing can be used to measure the influence of a factor to the radiative energy balance. Radiative forcing from aerosol is dependent on AOD, the capacity of aerosol absorption, and the underlying surface (Yoon et al., 2005). The criterion for the particle identified as fine-mode aerosol or coarse-mode aerosol is whether the $R_{d}$ is larger than 0.17 or not (as shown in Fig. 2) in this research. As a result, the fine-mode aerosol includes SA, MA, WA and NA, and the coarsemode aerosol contains the DUST, DD, and POD. In Fig. 7, we show top-of-atmosphere (TOA) and bottom-of-atmosphere (BOA) radiative forcing ( $\mathrm{F}_{\mathrm{TOA}}$ and $\mathrm{F}_{\mathrm{BOA}}$, respectively) and their difference, from fine-mode and coarse-mode aerosol. The solar flux was only evaluated for solar zenith angles (SZAs) between $50^{\circ}$ and $80^{\circ}$, which is where the solar geometry conditions are the most appropriate for retrieving aerosol properties (Dubovik et al., 2002).

The observations show that in northern China, fine-mode aerosol has stronger scattering ability than coarse-mode aerosol at the top and bottom of the atmosphere, with large quantity of heating retained in the air. The mean values of $\mathrm{F}_{\mathrm{TOA}}, \mathrm{F}_{\mathrm{BOA}}$, and the net radiative forcing for finemode aerosol in northern China is $-50.43 \mathrm{~W} \mathrm{~m}^{-2},-113.78 \mathrm{~W} \mathrm{~m}^{-2}$, and $63.35 \mathrm{~W} \mathrm{~m}^{-2}$, respectively. Previous research (Semenov et al., 2005) has suggested that the Issyk-Kul station, in Northwest Asia, showed nearly no radiative forcing because of low AOD. Therefore, this station is not included in the calculation of mean radiative forcing for this region. In Northwest Asia, the mean values of TOA and BOA radiative forcing is $-25.0 \mathrm{~W} \mathrm{~m}^{-2}$ and $-76.3 \mathrm{~W} \mathrm{~m}^{-2}$, respectively, giving a net value of $51.4 \mathrm{~W} \mathrm{~m}^{-2}$. Here, coarse-mode aerosol is the main contributor to backward scattering of solar radiation, leading to heating of the atmosphere, except in Dushanbe. In Dushanbe, finemode aerosol comes from the burning of fossil fuels for residential heating and cogeneration power stations, especially in winter which may strengthen the atmospheric heating effect of finemode particles (Yan et al., 2015). Emissions from anthropogenic activity, biomass burning and soot emissions, especially in winter (Zheng et al., 2017) induce a stronger heating effect in Beijing where there is a higher mean values of net radiative forcing for the total aerosol $\left(58.8 \mathrm{~W} \mathrm{~m}^{-2}\right)$. Contrast the two regions, the heating effect is more obvious in northern China and this phenomenon is corresponding to the high value of AOD and AAOD as shown in Fig. 3.

We reveal the radiative forcing results for stations in the three southern regions in Fig. 8 with regards to the radiative forcing of fine-mode aerosol; the atmosphere at the Namco station is much more pristine than that at any other site because it is located at a higher altitude. Therefore, this station was excluded when calculating the mean values of radiative forcing for the plateau region. The negative values of FTOA for fine- and coarse-mode aerosol in the three different regions suggest that the aerosol has a cooling effect in the earth-atmosphere system. Fine-mode aerosol is the main contributor to aerosol radiative forcing in the southern regions. The mean values of net radiative forcing in the plateau area, southern China and Southeast Asia for finemode aerosols are $77.1 \mathrm{~W} \mathrm{~m}^{-2}, 60.6 \mathrm{~W} \mathrm{~m}^{-2}, 39.5 \mathrm{~W} \mathrm{~m}^{-2}$, respectively. In contrast, the maximum net value appears in the south of the Tibetan Plateau (the Lumbini station), indicating the presence of strong absorptive aerosol released from biomass burning, which has a stronger 

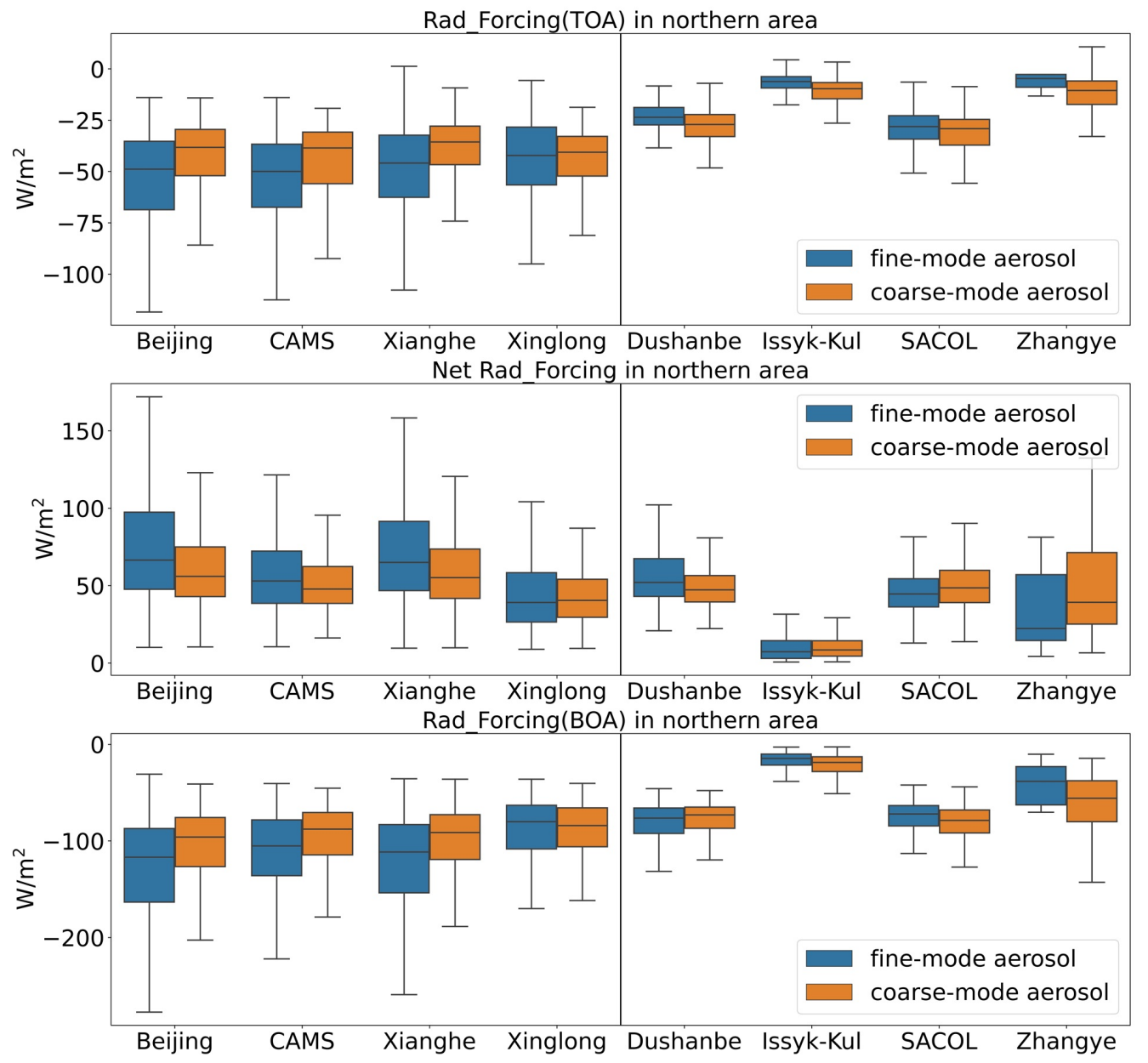

Fig. 7. Radiative forcing in the northern area, including at the top of the atmosphere, at the bottom of the atmosphere and the net radiative forcing (equal to the radiative flux in the air). The blue boxes and yellow boxes represent the radiative forcing from fine- and coarse-mode aerosol.

heating effect on the atmosphere. The net radiative forcing in southern China is smaller than that in northern China, in agreement with the results of Che et al. (2018), who reported that aerosol absorption is relatively weak in southern China (Che et al., 2018). The smallest net radiative forcing is found for the Southeast Asian region. This may result from the hygroscopic growth of fine-mode particles, which enhances scattering and reduces the solar energy reaching the ground. The high relative humidity environment in Southeast Asia also facilitates the formation of secondary aerosol species (Hennigan et al., 2008). The secondary aerosol species such as sulfate, nitrate and ammonium will further leading to a cooling effect and decreasing the solar energy stored on the air in Southeast Asia.

\subsection{Seasonal Dependence of Radiative Forcing and Radiative Forcing Efficiency for Fine-mode and Coarse-mode Aerosol}

Fig. 9 presents the seasonal trends for the net radiative forcing and net radiative forcing efficiency from fine-mode and coarse-mode aerosol at five principal sites. The data amount (the SSA and PLDR are all available) in five present stations for each season all exceed 100 to ensure the reliability. We analyze the radiative forcing properties and combine with seasonal variation of $A A O D, A A E$ from fine- and coarse-mode aerosol as shown in Fig. 10 to further understand the mechanism behind phenomenon.

In Beijing, the net radiative forcing from fine-mode aerosol is larger than that from coarsemode aerosol over the whole year, which means there are more absorptive and fine-mode aerosol suspended in the atmosphere over Beijing, due to the dense population and absorptive 

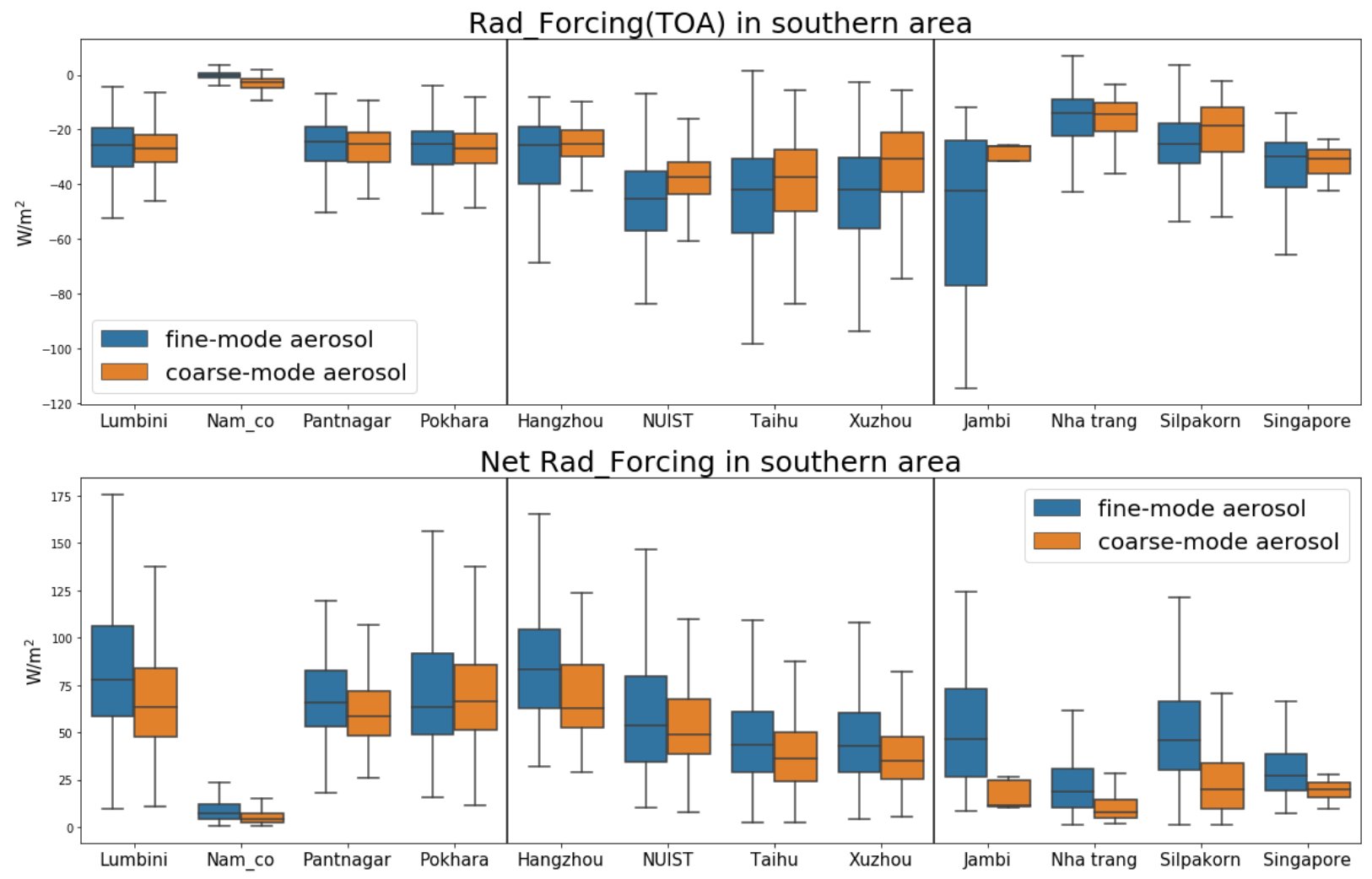

Rad_Forcing(BOA) in southern area

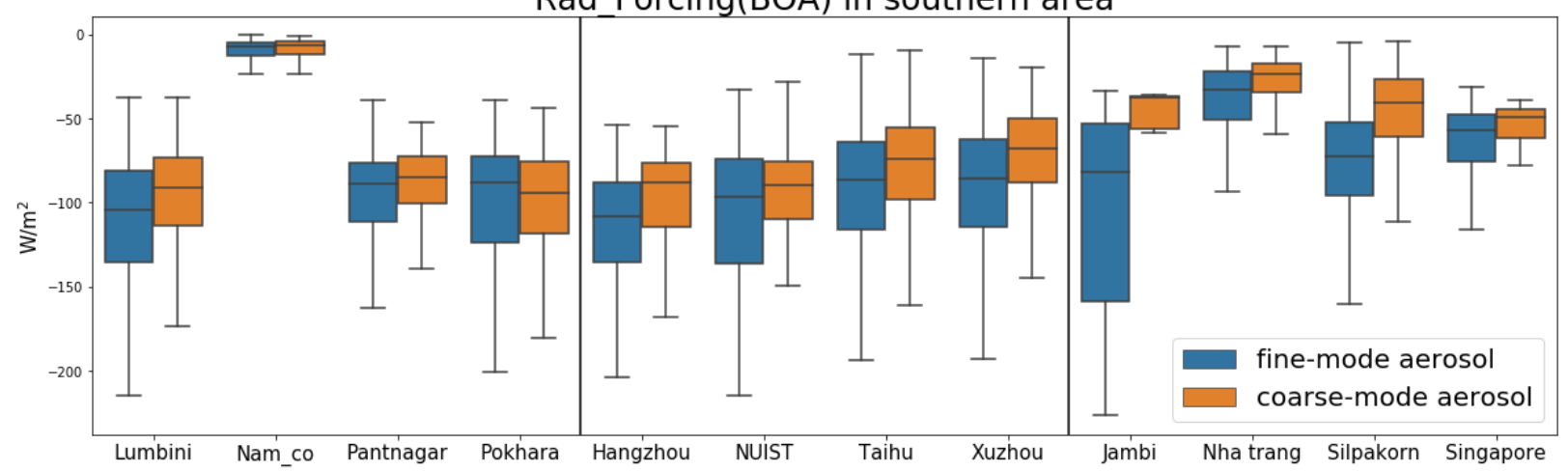

Fig. 8. As in Fig. 7 but for stations in the southern three regions. The blue boxes and yellow boxes represent the radiative forcing from fine- and coarse-mode aerosol.

nature of the aerosol released from fossil fuel burning. Results from Fig. 10 also reveal that it is fine-mode aerosol account for the large value of AAOD (AAOD from fine-mode aerosol in four seasons is $0.035,0.032,0.039$ and 0.035 ) although the AAE from coarse-mode aerosol is higher than that from fine-mode aerosol throughout the year. Residential heating in winter can contribute greatly to the heating effect in the atmosphere over northern China. 0.035 of AAOD from fine-mode aerosol and mean values of 1.62 about AAE from two kinds of aerosol produce the highest net radiative forcing $\left(81.5 \mathrm{~W} \mathrm{~m}^{-2}\right)$ during winter in Beijing. The net radiative forcing efficiency from coarse-mode particles is $65.3 \mathrm{~W} \mathrm{~m}^{-2}, 56.4 \mathrm{~W} \mathrm{~m}^{-2}, 58.1 \mathrm{~W} \mathrm{~m}^{-2}, 56.0 \mathrm{~W} \mathrm{~m}^{-2}$ in spring, summer, autumn, and winter, respectively, which for each season is higher than the corresponding value for fine-mode aerosol.

In Taihu, the lowest net radiative forcing from fine-mode aerosol $\left(35.7 \mathrm{~W} \mathrm{~m}^{-2}\right)$ and coarsemode aerosol $\left(20.3 \mathrm{~W} \mathrm{~m}^{-2}\right.$ ) occurs in summer. The mean values of AAOD and AAE from two kinds of aerosol are 0.01 and 1.04, which are minimum at the same time. The high ambient humidity in southern China is conducive to hygroscopic growth of fine-mode aerosol (Zhang et al., 2015), strengthening the scattering ability of aerosol and increasing solar radiation backscatter to the 

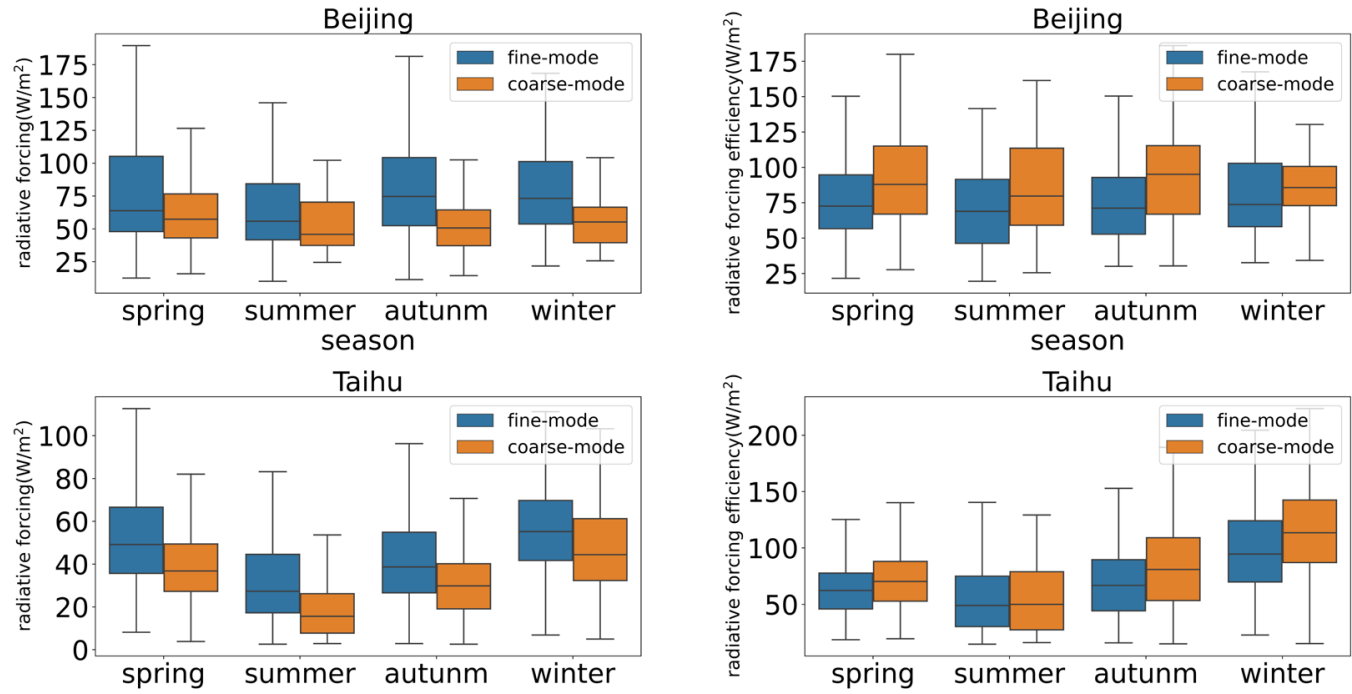

season

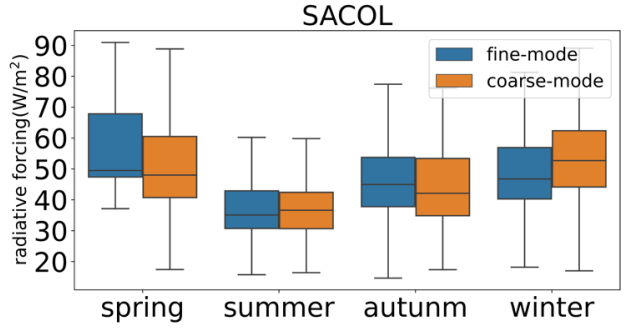

season

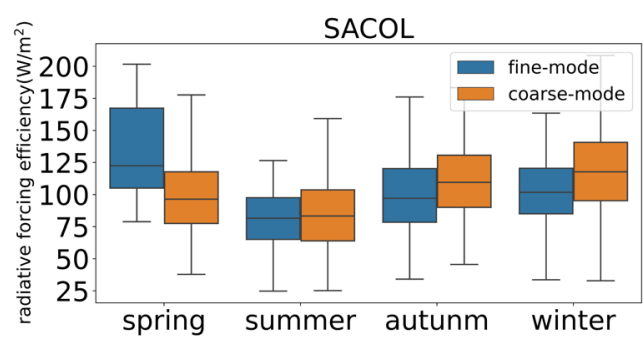

season
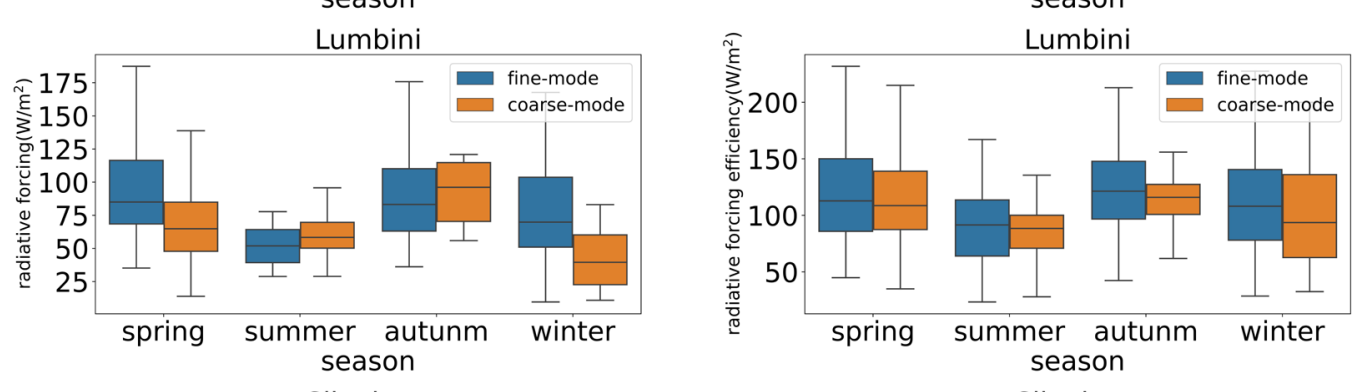

Silpakorn
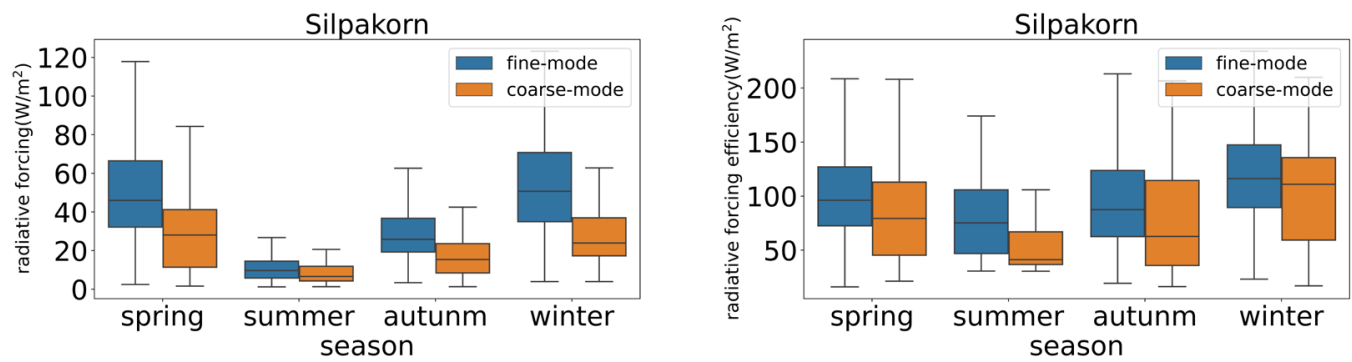

Fig. 9. The net radiative forcing and radiative forcing efficiency of fine-mode and coarse-mode aerosol at five principal stations in spring (March, April, May), summer (June, July, August), autumn (September, October, November) and winter (January, December, February). The blue boxes and yellow boxes represent the radiative forcing and radiative forcing efficiency from fineand coarse-mode aerosol.

top of the atmosphere. High values of net radiative forcing $\left(58.3 \mathrm{~W} \mathrm{~m}^{-2}\right.$ for fine-mode aerosol and $48.5 \mathrm{~W} \mathrm{~m}^{-2}$ for coarse-mode aerosol) occur in Taihu during winter, in good agreement with the low SSA values found in previous research (Xia et al., 2007b). The lowest net radiative forcing efficiency for fine-mode aerosol $\left(58.5 \mathrm{~W} \mathrm{~m}^{-2}\right)$ and coarse-mode aerosol $\left(56.6 \mathrm{~W} \mathrm{~m}^{-2}\right)$ occur in summer, which corresponding to the higher values of AOD compared with the other seasons $(0.84,0.88,0.8,0.75$ in spring, summer, autumn and winter, respectively). Highest net radiative 
forcing at SACOL from both kinds of aerosol appear in spring, with value of $59.6 \mathrm{~W} \mathrm{~m}^{-2}$ (finemode aerosol) and $52.8 \mathrm{~W} \mathrm{~m}^{-2}$ (coarse-mode aerosol). From Fig. 10, we can conclude that although the AAOD in SACOL during spring is not the highest $(0.015,0.011,0.016,0.018$ from coarse-mode aerosol in spring, summer, autumn, and winter, respectively), it is large value of AAE especially during spring (2.02) leading to the highest mean values of radiative forcing. Mineral dust particles in Northwest Asia may be coated with high-absorption components, which can prompt the absorption of dust aerosol. High net radiative forcing during winter may be partly due to the influence of high surface albedo in the region, leading to a heating effect on local climate (García et al., 2012). The mean values of net radiative forcing efficiency in spring are
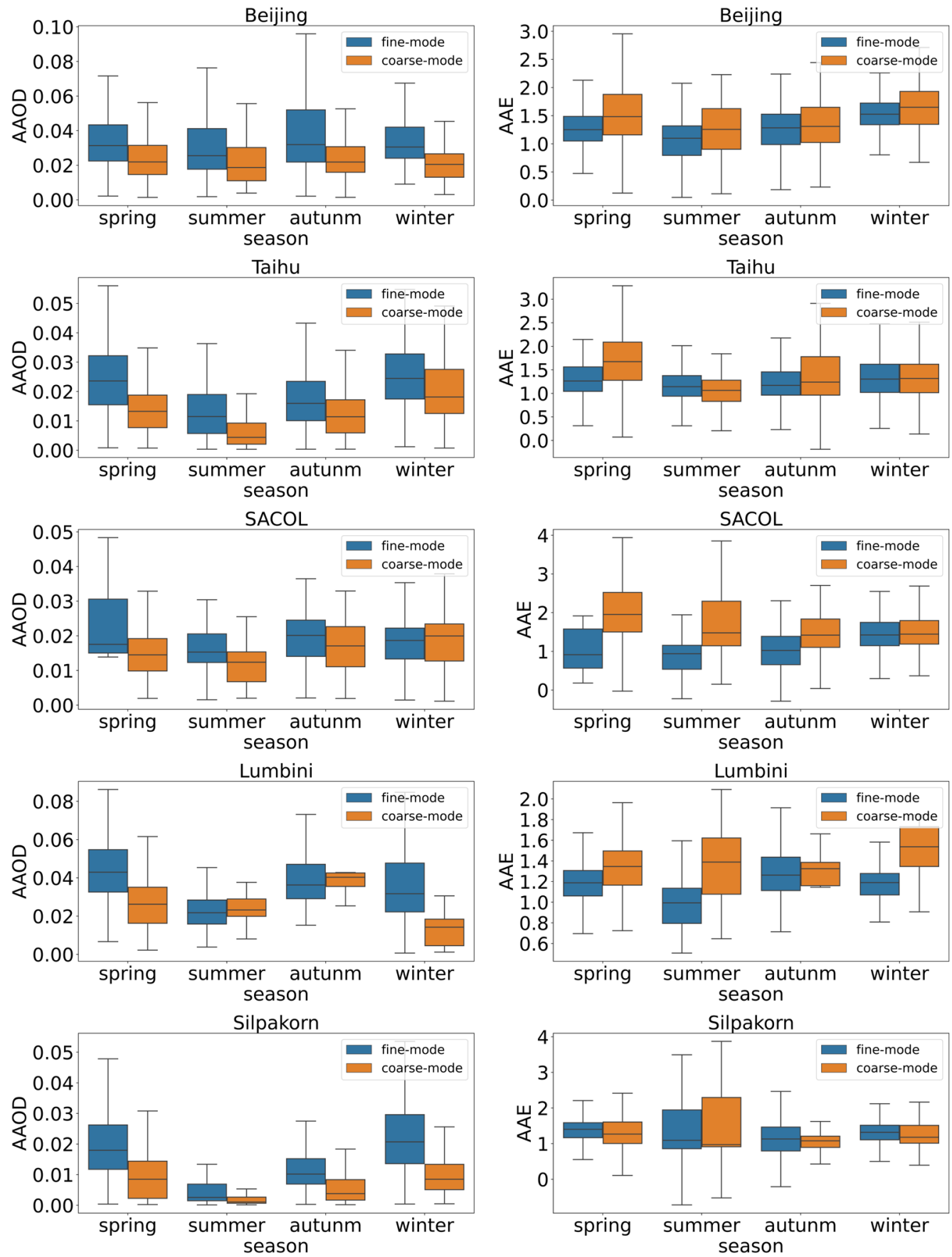

Fig. 10. As in Fig. 9 but for AAOD and AAE of fine-mode and coarse-mode aerosol at five principal stations in four seasons. The blue boxes and yellow boxes represent the parameters from fineand coarse-mode aerosol. 
133.6 $\mathrm{W} \mathrm{m}^{-2}$ and $99 \mathrm{~W} \mathrm{~m}^{-2}$ for fine- and coarse-mode aerosol, respectively, which is the highest of any season at this location. This signifies that coarse-mode aerosol is the main contributor to the high AOD in spring.

In Lumbini, high net radiative forcing values occur during pre-monsoon period and postmonsoon period; the mean values in the two periods are $81.5 \mathrm{~W} \mathrm{~m}^{-2}$ and $91.7 \mathrm{~W} \mathrm{~m}^{-2}$, respectively. The phenomenon above is corresponding to the seasonal variation of AAOD $(0.045,0.023,0.04$, 0.033 in spring, summer, autumn and winter, respectively) and $\operatorname{AAE}(1.19,0.95,1.30,1.19)$ from fine-mode aerosol as shown in Fig. 10. Previous research has shown that cement factory emissions and biomass burning from the residue of paddy and wheat in the harvest season result in high concentrations of absorptive aerosol during the two periods (Wan et al., 2017). These phenomena are conducive to high atmospheric radiative forcing in the air. The mean values of net radiative forcing efficiency of fine-mode aerosol for the whole year is highest $\left(110.3 \mathrm{~W} \mathrm{~m}^{-2}\right)$ when compared those from other four principal sites.

High net radiative forcing is found in spring and winter at Silpakorn in Southeast Asia, whereas the lowest net radiative forcing occurs in summer $\left(12.1 \mathrm{~W} \mathrm{~m}^{-2}\right.$ for fine-mode aerosol and 8.5 $\mathrm{W} \mathrm{m}^{-2}$ for coarse-mode aerosol). The temporal distribution of AAOD from fine-mode aerosol is also similar with this trend $(0.020,0.006,0.013,0.023$ in spring, summer, autumn and winter, respectively), higher in winter and spring but lower in summer. This is the result of high concentrations of SA aerosol in winter and high concentrations of NA aerosol in summer. The mean values of net radiative forcing efficiency for fine-mode aerosol is $102.25 \mathrm{~W} \mathrm{~m}^{-2}$, which is larger than that for coarse-mode aerosol $\left(81.3 \mathrm{~W} \mathrm{~m}^{-2}\right)$. In this regard, fine-mode aerosol heats the atmosphere more effectively than coarse-mode aerosol in this region.

\section{CONCLUSIONS}

We used PLDR and SSA values for $1020 \mathrm{~nm}$ from the AERONET Version 3 Level 2.0 dataset to differentiate seven types of aerosol in five regions of East and Southeast Asia. We investigated the aerosol optical parameters measured at various stations, characterized the spatial and temporal variation in the concentrations of the different aerosol types, and evaluated the seasonal radiative forcing and radiative forcing efficiency due to both the fine- and the coarse-mode aerosol in each region.

In northern China, pure dust contributed approximately $2 \%$ of the total aerosol. Compared to Northwest Asia, the air stored more heat, with a mean net radiative forcing of $63.35 \mathrm{~W} \mathrm{~m}^{-2}$ from the fine mode. Also, the large quantities of SA aerosol that occurred from November till spring corresponded to the high net radiative forcing observed during winter as a result of the fine mode.

The fine mode also dominated the aerosol in southern China, except during spring. Summer exhibited the lowest net radiative forcing efficiencies $\left(35.7 \mathrm{~W} \mathrm{~m}^{-2}\right.$ and $20.3 \mathrm{~W} \mathrm{~m}^{-2}$ for the fine and the coarse mode, respectively), owing to the AOD values peaking during this season, as well as the lowest mean AAOD (0.01) and AAE (1.04).

The AAOD and AAE values for Northwest Asia suggested that the aerosol in this region was lower in quantity but higher in absorptivity than that in northern China. Whereas the coarse mode contributed a large percentage of the total aerosol during most of the year, the fine mode became prevalent solely in autumn. Additionally, the purely dust aerosol reached its maximum concentration during April. Although Northwest Asia displayed only a moderate AAOD during spring, the high $A A E$, particularly in this season (2.02), led to the maximum mean radiative forcing values found in this study.

The SA fraction accounted for a considerable portion of the total aerosol on the Tibetan Plateau, especially during summer and September, thereby producing the strongest heating effect within the atmosphere. This phenomenon positively correlated with the seasonal variation in the AAOD and AAE of the fine-mode aerosol. Of the five studied regions, the Tibetan Plateau also possessed the highest mean annual net radiative forcing efficiency $\left(110.3 \mathrm{~W} \mathrm{~m}^{-2}\right)$ because of the fine mode, revealing the strong absorptive ability of the aerosol throughout the year.

Two distinct aerosol types prevailed in Southeast Asia. $20 \%$ of the aerosol on the Indochinese Peninsula during winter was SA, whereas the major contributors on the Malay Peninsula during summer were NA or WA, resulting in high and low net radiative forcing during winter and summer, 
respectively. The fine mode, not the coarse one, was primarily responsible for atmospheric heating in this region.

\section{ACKNOWLEDGMENTS}

Thanks to Arnico K. Panday, Bin Zhu, Brent Holben, Hong bin Chen, Hong Jiang, Jianping Huang, Lixin Wu, Musapar Orozaliev, Philippe Goloub, Pucai Wang, Ronghua Ma, Sabur F. Abdullaev, Santo V. Salinas Cortijo, Serm Janjai, Si-Chee Tsay, Shengjie Niu, Shichang Kang, Zhiyuan Cong, S.N. Tripathi, Soo Chin Liew, Wu Zhang, Xuan Anh Nguyen, Xiangao Xia for daily maintain the instrument and provide the Level 2.0 AERONET data. Lastly the article shows great gratitude to the National Key Research and Development Program of China (2019YFC1510400), the National Science Fund for Distinguished Young Scholars (41825011), and the National Natural Science Foundation of China (41975054 and 41930967) for financial support.

\section{REFERENCES}

Balasubramanian, R., Gao, X., Hatakeyama, S., Hwang, J., Tsai, C.J. (2017). Overview of the special issue" PM2.5 in Asia" for 2015 Asian aerosol conference. Aerosol Air Qual. Res. 17, 351-355. https://doi.org/10.4209/aaqr.2017.01.0042

Bergstrom, R.W., Pilewskie, P., Russell, P.B., Redemann, J., Bond, T.C., Quinn, P.K, Sierau, B. (2007). Spectral absorption properties of atmospheric aerosols. Atmos. Chem. Phys. 7, 59375943. https://doi.org/10.5194/acp-7-5937-2007

Bohren, C.F. and Huffman, D.R. (2008). Absorption and scattering of light by small particles. John Wiley \& Sons.

Cairo, F, Donfrancesco, G., Di, Adriani, A., Pulvirenti, L., Fierli, F. (1999). Comparison of various linear depolarization parameters measured by lidar. Appl. Opt. 38, 4425. https://doi.org/10.13 64/A0.38.004425

Cao, C., Zheng, S., Singh, R.P. (2014). Characteristics of aerosol optical properties and meteorological parameters during three major dust events (2005-2010) over Beijing, China. Atmos. Res. 150, 129-142. https://doi.org/10.1016/j.atmosres.2014.07.022

Che, H., Xia, X., Zhu, J., Li, Z., Dubovik, O., Holben, B., Goloub, P., Chen, H., Estelles, V., CuevasAgulló, E., Blarel, L., Wang, H., Zhao, H., Zhang, X., Wang, Y., Sun, J., Tao, R., Zhang, X., Shi, G. (2014). Column aerosol optical properties and aerosol radiative forcing during a serious haze-fog month over North China Plain in 2013 based on ground-based sunphotometer measurements. Atmos. Chem. Phys. 14, 2125-2138. https://doi.org/10.5194/acp-14-2125-2014

Che, H., Zhang, X.Y., Xia, X., Goloub, P., Holben, B., Zhao, H., Wang, Y., Zhang, X.C., Wang, H., Blarel, L., Damiri, B., Zhang, R., Deng, X., Ma, Y., Wang, T., Geng, F., Qi, B., Zhu, J., Yu, J., Chen, Q., Shi, G. (2015). Ground-based aerosol climatology of China: Aerosol optical depths from the China Aerosol Remote Sensing Network (CARSENT) 2002-2013. Atmos. Chem. Phys. 15, 76197652. https://doi.org/10.5194/acp-15-7619-2015

Che, H., Qi, B., Zhao, H., Xia, X., Eck, T.F., Goloub, P., Dubovik, O., Estelles, V., Cuevas-Agulló, E., Blarel, L., Wu, Y., Zhu, J., Du, R., Wang, Y., Wang, H., Gui, K., Yu, J., Zheng, Y., Sun, T., Chen, Q., Shi, G., Zhang, X. (2018). Aerosol optical properties and direct radiative forcing based on measurements from the China Aerosol Remote Sensing Network (CARSENT) in eastern China. Atmos. Chem. Phys. 18, 405-425. https://doi.org/10.5194/acp-18-405-2018

Chen, W.N., Chen, Y.W., Chou, C.C.K., Chang, S.Y., Lin, P.H., Chen, J.P. (2009). Columnar optical properties of tropospheric aerosol by combined lidar and sunphotometer measurements at Taipei, Taiwan. Atmos. Environ. 43, 2700-2708. https://doi.org/10.1016/j.atmosenv.2009.02.059

Deng, H., Chen, Y., Shi, X., Li, W., Wang, H., Zhang, S., Fang, G. (2014). Dynamics of temperature and precipitation extremes and their spatial variation in the arid region of northwest China. Atmos. Res. 138, 346-355. https://doi.org/10.1016/j.atmosres.2013.12.001

Dubovik, O., Holben, B., Eck, T.F., Smirnov, A., Kaufman, Y.J., King, M.D., Tanré, D., Slutsker, I. (2002). Variability of absorption and optical properties of key aerosol types observed in worldwide locations. J. Atmos. Sci. 59, 590-608. https://doi.org/10.1175/1520-0469(2002)059 $<0590$ :VOAAOP $>2.0 . \mathrm{CO} ; 2$ 
Dubovik, O., Sinyuk, A., Lapyonok, T., Holben, B.N., Mishchenko, M., Yang, P., Eck, T.F., Volten, H., Mufioz, O., Veihelmann, B. (2006). Application of spheroid models to account for aerosol particle nonsphericity in remote sensing of desert dust. J. Geophys. Res. 111, D11208. https://doi.org/10.1029/2005JD006619

Eck, T.F., Holben, B.N., Dubovik, O., Smirnov, A., Goloub, P., Chen, H.B., Chatenet, B., Gomes, L., Zhang, X.Y., Tsay, S.C., Ji, Q., Giles, D., Slutsker, I. (2005). Columnar aerosol optical properties at AERONET sites in central eastern Asia and aerosol transport to the tropical mid-pacific. J. Geophys. Res. 110, D06202. https://doi.org/10.1029/2004JD005274

Eck, T.F., Holben, B.N., Sinyuk, A., Pinker, R.T., Goloub, P., Chen, H., Chatenet, B., Li, Z., Singh, R.P., Tripathi, S.N., Reid, J.S., Giles, D.M., Dubovik, O., O'Neill, N.T., Smirnov, A., Wang, P., Xia, X. (2010). Climatological aspects of the optical properties of fine/coarse mode aerosol mixtures. J. Geophys. Res. 115, D19205. https://doi.org/10.1029/2010JD014002

Feng, N., Christopher, S.A. (2013). Satellite and surface-based remote sensing of Southeast Asian aerosols and their radiative effects. Atmos. Res. 122, 544-554. https://doi.org/10.1016/j.atmo sres.2012.02.018

Foyo-Moreno, I., Alados, I., Guerrero-Rascado, J.L., Lyamani, H., Pérez-Ramírez, D., Olmo, F.J., Alados-Arboledas, L. (2019). Contribution to column-integrated aerosol typing based on Sunphotometry using different criteria. Atmos. Res. 224, 1-17. https://doi.org/10.1016/j.atmosre s.2019.03.007

Freudenthaler, V., Esselborn, M., Wiegner, M., Heese, B., Tesche, M., Ansmann, A., Müller, D., Althausen, D., Wirth, M., Fix, A., Ehret, G., Knippertz, P., Toledano, C., Gasteiger, J., Garhammer, M., Seefeldner, M. (2009). Depolarization ratio profiling at several wavelengths in pure Saharan dust during SAMUM 2006. Tellus B 61, 165-179. https://doi.org/10.1111/j.16000889.2008.00396.x

García, O.E., Díaz, J.P., Expósito, F.J., Díaz, A.M., Dubovik, O., Derimian, Y., Dubuisson, P., Roger, J.C. (2012). Shortwave radiative forcing and efficiency of key aerosol types using AERONET data. Atmos. Chem. Phys. 12, 5129-5145. https://doi.org/10.5194/acp-12-5129-2012

García, O.E., Díaz, A.M., Expósito, F.J., Díaz, J.P., Dubovik, O., Dubuisson, P., Roger, J.C., Eck, T.F., Sinyuk, A., Derimian, Y. (2008). Validation of AERONET estimates of atmospheric solar fluxes and aerosol radiative forcing by ground-based broadband measurements. J. Geophys. Res. 113, 6089-6098. https://doi.org/10.1029/2008JD010211

Gong, S.L., Zhang, X.Y., Zhao, T.L., Mckendry, I.G., Jaffe, D.A., Lu, N.M. (2003). Characterization of soil dust aerosol in China and its transport and distribution during 2001 ACE-Asia: 2. Model simulation and validation. J. Geophys. Res. 108, 4262. https://doi.org/10.1029/2002JD002633

Gui, K., Che, H., Chen, Q., Zeng, Z., Zheng, Y., Long, Q., Sun, T., Liu, X., Wang, Y., Liao, T., Yu, J., Wang, H., Zhang, X. (2017). Water vapor variation and the effect of aerosols in China. Atmos. Environ. 165, 322-335. https://doi.org/10.1016/j.atmosenv.2017.07.005

Gui, K., Che, H., Wang, Y., Wang, H., Zhang, L., Zhao, H., Zheng, Y., Sun, T., Zhang, X. (2019). Satellite-derived $\mathrm{PM}_{2.5}$ concentration trends over Eastern China from 1998 to 2016: Relationships to emissions and meteorological parameters. Environ. Pollut. 247, 1125-1133. https://doi.org/ 10.1016/j.envpol.2019.01.056

Hennigan, C.J., Bergin, M.H., Dibb, J.E., Weber, R.J. (2008). Enhanced secondary organic aerosol formation due to water uptake by fine particles. Geophys. Res. Lett. 35, 102-102. https://doi.org/10.1029/2008GL035046

Hess, M., Koepke, P., Schult, I. (1998). Optical properties of aerosols and clouds: The software package OPAC. Bull. Am. Meteorol. Soc. 79, 831-844. https://doi.org/10.1175/1520-0477(199 8)079<0831:OPOAAC>2.0.CO;2

Holben, B.N., Eck, T.F., Slutsker, I., Tanré, D., Buis, J.P., Setzer, A., Vermote, E., Reagan, J.A., Kaufman, Y.J., Nakajima, T., Lavenu, F., Jankowiak, I., Smirnov, A. (1998). AERONET-A Federated Instrument Network and Data Archive for Aerosol Characterization. Remote Sens. Environ. 66, 1-16. https://doi.org/10.1016/S0034-4257(98)00031-5

Holben, B.N., Tanre, D., Smirnov, A., Eck, T.F., Slutsker, I., Abuhassan, N., Newcomb, W.W., Schafer, J.S., Chatenet, B., Lavenu, F. (2001). An emerging ground-based aerosol climatology: Aerosol optical depth from AERONET. J. Geophys. Res. 106, 12067-12097. https://doi.org/10.1 029/2001JD900014

Huebert, B.J., Bates, T., Russell, P.B., Shi, G., Kim, Y.J., Kawamura, K., Carmichael, G., Nakajima, T. 
(2003). An overview of ACE-Asia: Strategies for quantifying the relationships between Asian aerosols and their climatic impacts. J. Geophys. Res. 108, 8633. https://doi.org/10.1029/2003 JD003550

IPCC (2013). Climate Change 2013: The Physical Science Basis. Contribution of Working Group I to the Fifth Assessment Report of the Intergovernmental Panel on Climate Change. Cambridge University Press, Cambridge, United Kingdom and New York, NY, USA.

Khan, R., Kumar, K.R., Zhao, T. (2019). The climatology of aerosol optical thickness and radiative effects in Southeast Asia from 18-years of ground-based observations. Environ. Pollut. 254, 113025. https://doi.org/10.1016/j.envpol.2019.113025

Kim, J., Lee, J., Lee, H.C., Higurashi, A., Takemura, T., Song, C.H. (2007). Consistency of the aerosol type classification from satellite remote sensing during the Atmospheric Brown Cloud-East Asia Regional Experiment campaign. J. Geophys. Res. 112, D22S33. https://doi.org/10.1029/2006JD 008201

Kusumaningtyas, S.D.A. (2019). Aerosol optical depth (AOD) over four Indonesian cities from the AERONET measurement: An overview. JSTMC 20, 47-57. https://doi.org/10.29122/jstmc.v20i 2.3894

Lee, J., Kim, J., Song, C.H., Kim, S.B., Chun, Y., Sohn, B.J., Holben, B.N. (2010). Characteristics of aerosol types from AERONET sunphotometer measurements. Atmos. Environ. 44, 3110-3117. https://doi.org/10.1016/j.atmosenv.2010.05.035

Li, S., Wang, T., Xie, M., Han, Y., Zhuang, B. (2015). Observed aerosol optical depth and angstrom exponent in urban area of Nanjing, China. Atmos. Environ. 123, 350-356. https://doi.org/10.1 016/j.atmosenv.2015.02.048

Liu, H., Pinker, R.T., Holben, B.N. (2005). A global view of aerosols from merged transport models, satellite, and ground observations. J. Geophys. Res. 110, D10S15. https://doi.org/10.1029/20 04JD004695

Lolli, S., Khor, W.Y., Matjafri, M.Z., Lim, H.S. (2019). Monsoon season quantitative assessment of biomass burning clear-sky aerosol radiative effect at surface by ground-based lidar observations in Pulau Pinang, Malaysia in 2014. Remote Sensing. 11, 2660. https://doi.org/10.3390/rs11222660

Ma, Y., Xin, J., Ma, Y., Kong, L., Zhang, K., Zhang, W., Wang, Y., Wang, X., Zhu, Y. (2017). Optical properties and source analysis of aerosols over a desert area in Dunhuang, Northwest China. Adv. Atmos. Sci. 34, 1017-1026. https://doi.org/10.1007/s00376-016-6224-6

Mamouri, R.E., Ansmann, A. (2017). Potential of polarization/Raman lidar to separate fine dust, coarse dust, maritime, and anthropogenic aerosol profiles. Atmos. Meas. Tech. 10, 3403-3427. https://doi.org/10.5194/amt-10-3403-2017

Mielonen, T., Arola, A., Komppula, M., Kukkonen, J., Koskinen, J., Leeuw, G.D., Lehtinen, K.E.J. (2009). Comparison of CALIOP level 2 aerosol subtypes to aerosol types derived from AERONET inversion data. Geophys. Res. Lett. 36, 252-260. https://doi.org/10.1029/2009GL039609

Noh, Y., Müller, D., Lee, K., Kim, K., Lee, K., Shimizu, A., Sano, I., Park, C.B. (2017). Depolarization ratios retrieved by AERONET sun-sky radiometer data and comparison to depolarization ratios measured with lidar. Atmos. Chem. Phys. 17, 6271-6290. https://doi.org/10.5194/acp-176271-2017

Pandithurai, G., Dipu, S., Dani, K.K., Tiwari, S., Bisht, D.S., Devara, P.C.S., Pinker, R.T. (2008). Aerosol radiative forcing during dust events over New Delhi, India. J. Geophys. Res. 113, D13209. https://doi.org/10.1029/2008JD009804

Ramanathan, V., Ramana, M.V. (2005). Persistent, widespread, and strongly absorbing haze over the Himalayan foothills and the Indo-Gangetic Plains. Pure Appl. Geophys. 162, 1609-1626. https://doi.org/10.1007/s00024-005-2685-8

Rupakheti, D., Adhikary, B., Kang, S., Mahata, K., Naja, M., Zhang, Q., Panday, A., Lawrence, M. (2017). Pre-monsoon air quality over Lumbini, a world heritage site along the Himalayan foothills. Atmos. Chem. Phys. 17, 1-46. https://doi.org/10.5194/acp-2016-430

Rupakheti, D., Kang, S., Rupakheti, M., Cong, Z., Panday, A.K., Holben, B.N. (2019). Identification of absorbing aerosol types at a site in the northern edge of Indo- Gangetic Plain and a polluted valley in the foothills of the central Himalayas. Atmos. Res. 223, 15-23. https://doi.org/10.10 16/j.atmosres.2019.03.003

Russell, P.B., Bergstrom, R.W., Shinozuka, Y., Clarke, A.D., DeCarlo, P.F., Jimenez, J.L., Livingston, J.M., Redemann, J., Dubovik, O., Strawa, A. (2010). Absorption angstrom exponent in AERONET 
and related data as an indicator of aerosol composition. Atmos. Chem. Phys. 10, 1155-1169. https://doi.org/10.5194/acp-10-1155-2010

Salinas, S.V., Chew, B.N., Liew, S.C. (2009). Retrievals of aerosol optical depth and Ångström exponent from ground-based Sun-photometer data of Singapore. Appl. Opt. 48, 1473-1484. https://doi.org/10.1364/AO.48.001473

Satheesh, S.K., Krishna Moorthy, K. (2005). Radiative effects of natural aerosols: A review. Atmos. Environ. 39, 2089-2110. https://doi.org/10.1016/j.atmosenv.2004.12.029

Schuster, G.L., Dubovik, O., Holben, B.N. (2006). Angstrom exponent and bimodal aerosol size distributions. J. Geophys. Res. 111, D07207. https://doi.org/10.1029/2005JD006328

Semenov, V.K., Smirnov, A., Aref'ev, V.N., Sinyakov, V.P., Sorokina, L.I., Ignatova, N.I. (2005). Aerosol optical depth over the mountainous region in central Asia (Issyk-Kul Lake, Kyrgyzstan). Geophys. Res. Lett. 32, L05807. https://doi.org/10.1029/2004GL021746

Sheng, Z., Che, H., Chen, Q., Xia, X.A., Liu, D., Wang, Z., Zhao, H., Gui, K., Zheng, Y., Sun, T., Li, X., Liu, C., Wang, H., Wang, Y., Zhang, X. (2019). Aerosol vertical distribution and optical properties of different pollution events in Beijing in autumn 2017. Atmos. Res. 215, 193-207. https://doi.org/10.1016/j.atmosres.2018.08.029

Shimizu, A., Sugimoto, N., Matsui, I., Arao, K., Uno, I., Murayama, T., Kagawa, N., Aoki, K., Uchiyama, A., Yamazaki, A. (2004). Continuous observations of Asian dust and other aerosols by polarization lidars in China and Japan during ACE-Asia. J. Geophys. Res. 109, D19S17. https://doi.org/10.1029/2002JD003253

Shin, S.K., Müller, D., Lee, C., Lee, K.H., Shin, D., Kim, Y.J., Noh, Y.M. (2015). Vertical variation of optical properties of mixed Asian dust/pollution plumes according to pathway of air mass transport over East Asia. Atmos. Chem. Phys. 15, 6707-6720. https://doi.org/10.5194/acpd15-3381-2015

Shin, S.K., Tesche, M., Kim, K., Kezoudi, M., Tatarov, B., Müller, D., Noh, Y. (2018). On the spectral depolarisation and lidar ratio of mineral dust provided in the AERONET version 3 inversion product. Atmos. Chem. Phys. 18, 12735-12746. https://doi.org/10.5194/acp-2018-401

Shin, S.K., Tesche, M., Noh, Y., Müller, D. (2019). Aerosol-type classification based on AERONET version 3 inversion products. Atmos. Meas. Tech. 12, 3789-3803. https://doi.org/10.5194/am t-12-3789-2019

Smirnov, A., Holben, B., Eck, T., Dubovik, O., Slutsker, I. (2000). Cloud screening and Quality Control Algorithms for the AERONET database. 73, 337-349. https://doi.org/10.1016/S00344257(00)00109-7

Sun, T., Che, H., Qi, B., Wang, Y., Dong, Y., Xia, X., Wang, H., Gui, K., Zheng, Y., Zhao, H., Ma, Q., $\mathrm{Du}, \mathrm{R}$. , Zhang, X. (2019). Characterization of vertical distribution and radiative forcing of ambient aerosol over the Yangtze River Delta during 2013-2015. Sci. Total Environ. 650, 18461857. https://doi.org/10.1016/j.scitotenv.2018.09.262

Tan, F., San Lim, H., Abdullah, K., Yoon, T.L., Holben, B. (2015). AERONET data-based determination of aerosol types. Atmo. Pollut. Res. 6, 682-695. https://doi.org/10.5094/APR.2015.077

Tesche, M., Müller, D., Gross, S., Ansmann, A., Althausen, D., Freudenthaler, V., Weinzierl, B. Veira, A., Petzold, A. (2011). Optical and microphysical properties of smoke over Cape Verde inferred from multiwavelength lidar measurements. Tellus 63, 677-694. https://doi.org/10.11 11/j.1600-0889.2011.00549.x

Toledano, C., Cachorro, V.E., Berjon, A., de Frutos, A.M., Sorribas, M., de la Morena, B.A., Goloub, P. (2007). Aerosol optical depth and Ångström exponent climatology at el Arenosillo AERONET site (Huelva, Spain). Q. J. R. Meteorolog. Soc. 133, 795-807. https://doi.org/10.1002/qj.54

Wan, X., Kang, S., Li, Q., Rupakheti, D., Zhang, Q., Guo, J., Chen, P., Tripathee, L., Rupakheti, M. Panday, A.K. (2017). Organic molecular tracers in the atmospheric aerosols from Lumbini, Nepal, in the northern Indo-Gangetic Plain: Influence of biomass burning. Atmos. Chem. Phys. 17, 8867-8885. https://doi.org/10.5194/acp-17-8867-2017

Wang, Z., Liu, D., Wang, Z., Wang, Y., Khatri, P., Zhou, J., Takamura, T., Shi, G.J. (2014). Seasonal characteristics of aerosol optical properties at the SKYNET Hefei site $\left(31.90^{\circ} \mathrm{N}, 117.17^{\circ} \mathrm{E}\right)$ from 2007 to 2013. J. Geophys. Res. 119, 6128-6139. https://doi.org/10.1002/2014JD021500

Xia, X., Chen, H., Goloub, P., Zhang, W., Chatenet, B., Wang, P. (2007a). A compilation of aerosol optical properties and calculation of direct radiative forcing over an urban region in northern China. J. Geophys. Res. 112, D12203. https://doi.org/10.1029/2006JD008119 
Xia, X., Li, Z., Holben, B., Wang, P., Eck, T., Chen, H., Cribb, M., Zhao, Y. (2007b). Aerosol optical properties and radiative effects in the Yangtze Delta region of China. J. Geophys. Res. 112, D22S12. https://doi.org/10.1029/2007jd008859

Xin, J., Gong, C., Wang, S., Wang, Y. (2016). Aerosol direct radiative forcing in desert and semidesert regions of northwestern China. Atmos. Res. 171, 5665. https://doi.org/10.1016/j.atmos res.2015.12.004

Yan, N., Wu, G., Zhang, X., Zhang, C., Xu, T., Lazhu (2015). Variation of aerosol optical properties from AERONET observation at Mt. Muztagh Ata, Eastern Pamirs. Atmos. Res. 153, 480-488. https://doi.org/10.1016/j.atmosres.2014.10.013

Yoon, S.C., Won, J.G., Omar, A.H., Kim, S.W., Sohn, B.J. (2005). Estimation of the radiative forcing by key aerosol types in worldwide locations using a column model and AERONET data. Atmos. Environ. 39, 6620-6630. https://doi.org/10.1016/j.atmosenv.2005.07.058

Yu, X., Rui, L., Kumar, K.R., Ma, J., Zhang, Q., Jiang, Y., Kang, N., Yang, S., Wang, J., Li, M. (2016). Dust aerosol properties and radiative forcing observed in spring during 2001-2014 over urban Beijing, China. Environ. Sci. Pollut. Res. Int. 23, 15432-15442. https://doi.org/10.1007/s11356016-6727-9

Zhang, L., Sun, J.Y., Shen, X.J., Zhang, Y.M., Che, H., Ma, Q.L., Zhang, Y.W., Zhang, X.Y., Ogren, J.A (2015). Observations of relative humidity effects on aerosol light scattering in the Yangtze River Delta of China. Atmos. Chem. Phys. 15, 8439-8454. https://doi.org/10.5194/acp-15-84392015

Zhang, X.Y., Arimoto, R., Zhu, G.H., Chen, T., Zhang, G.Y. (1998). Concentration, size-distribution and deposition of mineral aerosol over Chinese desert regions. Tellus B 50, 317-330. https://doi.org/10.3402/tellusb.v50i4.16131

Zhang, X.Y., Wang, Y.Q., Niu, T., Zhang, X.C., Gong, S.L., Zhang, Y.M., Sun, J.Y. (2012). Atmospheric aerosol compositions in China: spatial/temporal variability, chemical signature, regional haze distribution and comparisons with global aerosols. Atmos. Chem. Phys. 12, 779-799. https://doi.org/10.5194/acp-12-779-2012

Zhao, H., Che, H., Ma, Y., Xia, X., Wang, Y., Wang, P., Wu, X. (2015). Temporal variability of the visibility, particulate matter mass concentration and aerosol optical properties over an urban site in Northeast China. Atmos. Res. 166, 204-212. https://doi.org/10.1016/j.atmosres.2015.0 7.003

Zheng, C., Zhao, C., Zhu, Y., Wang, Y., Shi, X., Wu, X., Chen, T., Wu, F., Qiu, Y. (2017). Analysis of influential factors for the relationship between $\mathrm{PM}_{2.5}$ and $A O D$ in Beijing. Atmos. Chem. Phys. 17, 13473-13489. https://doi.org/10.5194/acp-2016-1170

Zhu, J., Che, H., Xia, X., Chen, H., Goloub, P., Zhang, W. (2014). Column-integrated aerosol optical and physical properties at a regional background atmosphere in North China Plain. Atmos. Environ. 84, 54-64. https://doi.org/10.1016/j.atmosenv.2013.11.019

Zhu, J., Xia, X., Che, H., Wang, J., Cong, Z., Zhao, T., Kang, S., Zhang, X., Yu, X., Zhang, Y. (2019). Spatiotemporal variation of aerosol and potential long-range transport impact over the Tibetan Plateau, China. Atmos. Chem. Phys. 19, 14637-14656. https://doi.org/10.5194/acp19-14637-2019 